\title{
Paleoecological Perspectives on Fire Ecology: Revisiting the Fire-Regime Concept
}

\author{
Cathy Whitlock ${ }^{*}$, Philip E. Higuera ${ }^{\dagger}$, David B. McWethy and Christy E. Briles ${ }^{*}$
}

Department of Earth Sciences, Montana State University, Bozeman MT 59717, USA

\begin{abstract}
Fire is well recognized as a key Earth system process, but its causes and influences vary greatly across spatial and temporal scales. The controls of fire are often portrayed as a set of superimposed triangles, with processes ranging from oxygen to weather to climate, combustion to fuel to vegetation, and local to landscape to regional drivers over broadening spatial and lengthening temporal scale. Most ecological studies and fire management plans consider the effects of fire-weather and fuels on local to sub-regional scales and time frames of years to decades. Fire reconstructions developed from high-resolution tree-ring records and lake-sediment data that span centuries to millennia offer unique insights about fire's role that cannot otherwise be obtained. Such records help disclose the historical range of variability in fire activity over the duration of a vegetation type; the role of large-scale changes of climate, such as seasonal changes in summer insolation; the consequences of major reorganizations in vegetation; and the influence of prehistoric human activity in different ecological settings. This paleoecological perspective suggests that fire-regime definitions, which focus on the characteristic frequency, size and intensity of fire and particular fuel types, should be reconceptualized to better include the controls of fire regimes over the duration of a particular biome. We suggest that approaches currently used to analyze fire regimes across multiple spatial scales should be employed to examine fire occurrence across multiple temporal scales. Such cross-scale patterns would better reveal the full variability of particular fire regimes and their controls, and provide relevant information for the types of fire regimes likely to occur in the future with projected climate and land-use change.
\end{abstract}

Keywords: Fire history, fire triangle, fire-climate, fire-human, fire-vegetation, charcoal records, fire regimes.

\section{INTRODUCTION}

Fire is widely recognized as a critical component of the Earth system, with influences on carbon and energy balances, climate change, and ecosystem dynamics over multiple temporal and spatial scales (Bowman et al. 2009; Flannigan et al. 2009). Understanding the present role of fire from local to regional to global scales requires placing current biomass burning into a temporal framework that considers the long-term influence of different natural and human drivers. Historical information on fires comes from satellite observations of the last two decades, documentary records that extend back centuries, tree-ring data that span centuries to millennia, and long-term sediment and geologic records that cover several millennia. Recent advances in firehistory research offer new approaches for reconstructing past fire occurrence over multiple temporal and spatial scales (Veblen et al. 2003, Gavin et al. 2007, Swetnam and Anderson 2008, Power et al. 2008). The insights provided by these approaches suggest the need to re-examine fire's role as an ecosystem process and motivate this review.

\footnotetext{
*Address correspondence to this author at the Department of Earth Sciences, Montana State University, Bozeman MT 59717, USA; Tel: 406994-6910; E-mail: whitlock@montana.edu

Current address: Department of Forest Resources, University of Idaho, P.O. Box 441133 Moscow, ID, USA 83844-1133

${ }^{*}$ Current address: Department of Anthropology, Texas A\&M University (TAMU 4352), College Station, TX, USA 77843-4352
}

Special Issue Editor: Valentí Rull
Disturbance regimes are described by their type, frequency, predictability, extent, magnitude, synergism with other disturbances, and seasonality (White and Pickett 1985, Agee 1993, Baker 2009). A fire regime describes the characteristics of fire and its role in a particular ecosystem. A suite of climate, fuel, and landscape variables is required for fire to occur and spread, although their relative importance changes across scales. Fire triangles are a common starting point for conceptualizing the interaction of these variables, and the elements of the triangles are nested and together define a range of conditions, from those that start fires at the local scale to those that consider fire as an Earth system process at the global scale (Fig. 1). Describing the drivers of fire at the smallest scales, the fire-fundamentals triangle links oxygen, heat, and fuel at hourly-to-annual time scales, and the fire-event triangle links weather, fuels, and topography as factors that influence ignition probability, rate-of-fire spread, and fire intensity at seasonal-to-annual time scales (Rothermel 1972, Pyne 1996). On decadal-tomillennial time scales, the fire-regime triangle includes variables that determine the characteristic pattern, frequency, and intensity of fire at landscape and larger spatial scales. The fire-regime triangle defines the linkages between vegetation, which is a determinant of broad-scale fuel characteristics, climate conditions that support fire weather, and ignition sources, be they human or natural (Moritz et al. 2005, Parisien and Moritz 2009). The super-fire regime triangle that represents the largest and longest controls will be discussed later. 


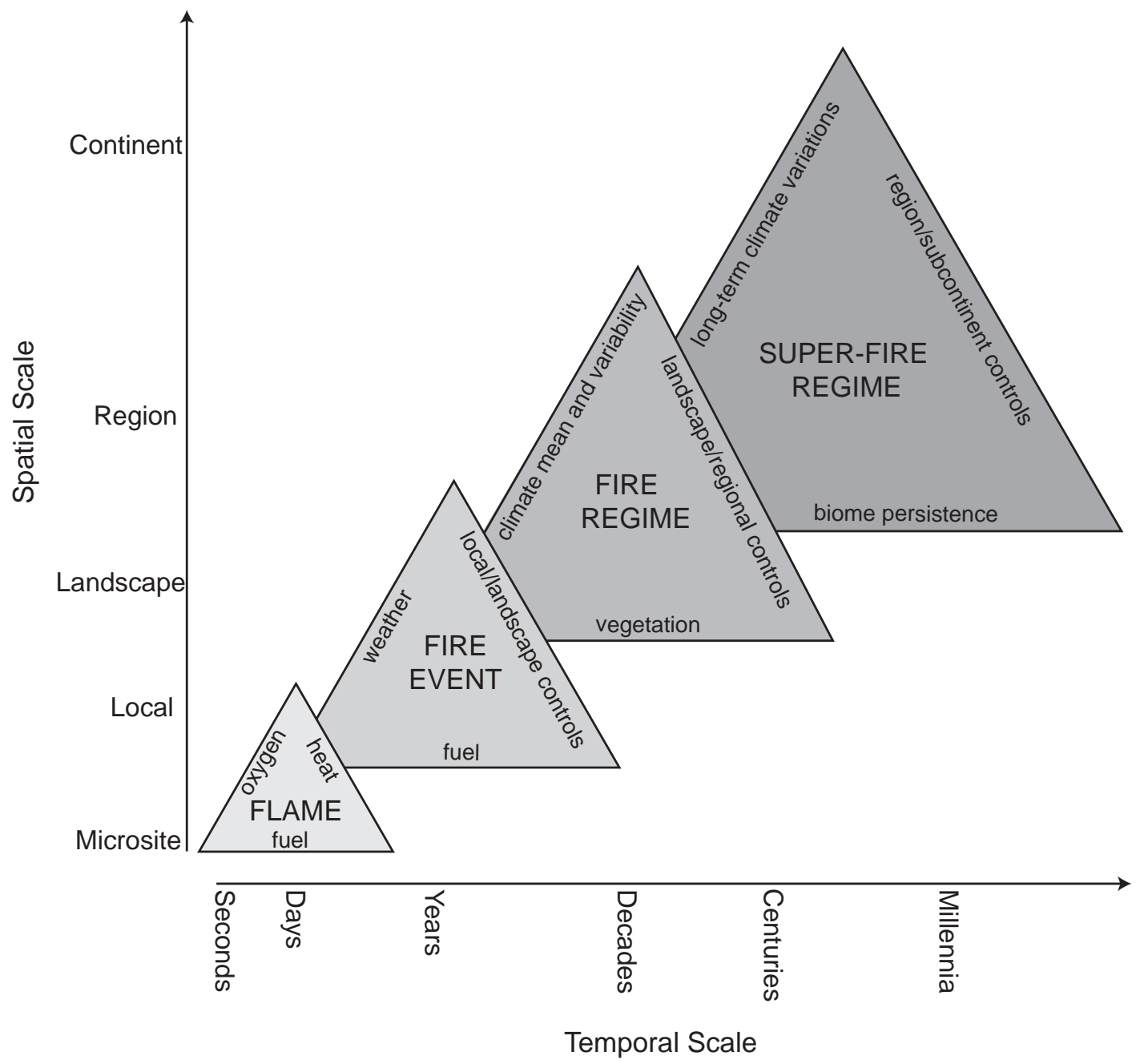

Fig. (1). Controls of fire at multiple temporal and spatial scales conceptualized as fire triangles (modified from Parisien and Moritz 2009). The side of each triangle indicates the dominant drivers at different temporal spatial scales, and the overlap of triangles shows their nested nature. The long temporal perspective offered by paleoecological data suggest the need for a broader conceptualization of fire regimes and perhaps even a new super-fire regime triangle that considers the variability of fire characteristics over the lifespan and spatial extent of a biome.

Each triangle is complex and supported by targeted research on specific interactions, but fire science until recently has largely focused on aspects of the small and intermediate fire triangles that address immediate risk concerns. In general, fires occur in the middle range of many of these variables, i.e., in places where fuels are sufficient, dry weather is conducive for combustion and fire spread, and ignitions are frequent. At environmental extremes are dry areas where sparse discontinuous plant cover prohibits fire spread, and wet settings where fuel is abundant but often too moist to burn and natural ignitions are scarce, so that natural fires are rare. The wildcard is human activities. Our conceptualization of fire triangles places the greatest human influence in shaping the fire-regime triangle, yet human effects are present at all scales (Dantonio and Vitousek 1992).

Management objectives focused on ecosystem sustainability require information from the fire-regime triangle, and these human-vegetation-climate linkages have gained wider attention in the face of projected future climate change.
Although many definitions of fire regime implicitly consider time, historical data have rarely been used to define fire regimes. We argue that fire-regime definitions are flawed without explicit consideration of a time domain that includes many fires and identifies the long-term characteristic climate and fuel drivers.

The two primary records of long-term fire history come from tree rings (fire scars and stand ages) and charcoal time series from lake and bog sediment cores, and recent advancements in analyzing and interpreting such data makes their results accessible to other disciplines, including ecology (Conedera et al. 2009). For most parts of the world, sitespecific records are available to infer local fire history; in many regions, networks of records are available to examine fire activity at broader scales. In this review, we describe the elements of the fire-regime triangle gained from a paleoecological perspective. In particular, we examine (1) climate influences of different duration and intensity as a top-down driver of fire activity; (2) fuel, vegetation, and biomes as bottom-up determinants of fire regimes; and (3) the role that 
humans play in modifying fire regimes and facilitating ecosystem transformation. Finally, we suggest a new conceptualization of fire regimes to help integrate our understanding across multiple temporal scales. Our examples are drawn largely from our own experience working in temperate and boreal ecosystems, although we believe that our conclusions are broadly applicable.

\section{FIRE-WEATHER AND FIRE-CLIMATE LINKAGES}

Weather and climate influence fire behavior and fire regimes over scales from minutes to millennia, and the processes on one scale strongly influence the outcomes at another. In a given fire season, for example, weather conditions, including precipitation, humidity, air temperature, lightning, and wind, determine fire behavior through their influence on fuel moisture, ignition rates, and fire spread (Weber and Flannigan 1997, Rothermel 1972). In many regions, the timing of ignition, increasing evaporative demand, and decreasing soil moisture levels are closely related over a two-to-three month period (Bartlein et al. 2008, Hostetler et al. 2003). These weather conditions are embedded in large-scale climate anomalies, which develop over the course of months to years and influence the annual area burned (e.g., Skinner et al. 1999, Kitzberger and Veblen 2003, Littell et al. 2009). Years of high area burned are related to the persistence of large atmospheric circulation features and their ultimate influence on ignitions and fuel moisture. Climate dynamics establish these anomalies and determine their persistence and frequency over decades and centuries. Although measurements of fire outcomes vary on different temporal scales, fire-history data ultimately reflect individual fire years and the role of weather and climate conditions in ignitions, fuel moisture, and fire spread. In middle and low latitudes, the strength of subtropical highpressure systems, moisture fluxes related to monsoonal circulation, and the specific location of convectional storms govern the severity of the fire season (Duffy et al. 2005, Gedalof et al. 2005, Skinner et al. 1999). During the 19971998 El Niño, for example, fires were widespread in southern South America, as a result of the development of a stronger upper-level ridge to the southwest of the southern tip of South America and a trough over northern Argentina (Whitlock et al. 2007). The longitudinal patterns of $500 \mathrm{mb}$ wind speeds showed weaker-than-normal winds over the continent and stronger-than-normal winds to the south of the continent, i.e., a southward shift in the band of fastest westerlies. Vertical subsidence over southern South America resulted in lower-than-normal precipitation in the areas experiencing fire.

The frequency and character of these fire-conducive climate conditions are geographic and temporal constraints on fire activity, both through directly controlling fire weather and indirectly affecting the quality and quantity of fuels. As the time scale of consideration lengthens, the climate conditions that lead to frequent low-severity fires as opposed to infrequent high-severity fires start to become evident. For example, on decadal-to-multidecadal time scales, fireclimate in some North American regions is related to the changing importance of modes of climate variability, including the El Niño Southern Oscillation (ENSO), Pacific Decadal Oscillation (PDO), and the Atlantic Monthly
Oscillation (AMO). A compilation of wildfires based on 30,000 fire-scars from 238 tree-ring chronologies in the western U.S. suggests that large-scale fire patterns are tied to continental patterns of drought and interannual and decadal climate variability (Kitzberger et al. 2007). ENSO variability partially explains differences in fire history between the Pacific Northwest and the American Southwest, but within these regions, synchrony in fire occurrence seems related to particular phases of ENSO, PDO, and AMO. Prolonged and severe droughts have been associated with positive phases of ENSO and/or PDO in the Pacific Northwest, and their persistence has led to large-fire years as well as decades and centuries of high area burned (Littell et al. 2009, Fauria and Johnson 2008, Heyerdahl et al. 2008, Schoennagel et al. 2007, Gedalof et al. 2005). The opposite is observed in the American Southwest, where cold La Niña events are associated with drought and fire.

High fire activity has also been associated with warm, effectively dry decades during the Medieval Climate Anomaly ( 900-1300 AD) and the Roman Warm Period $(\sim 200$ BC-600 AD) in several parts of western North America (Pierce et al. 2004; Swetnam 1993, Cook et al. 2004). Fewer fires occurred during the Little Ice Age ( 1600-1850 AD). Such changes in fire activity driven by multi-decadal climate variability have altered patterns of tree mortality and recruitment, forest community dynamics, and disturbance synergisms (e.g., Bigler et al. 2007, Sherriff and Veblen 2007, Brown 2006).

Climate drivers operating on centennial-to-millennial time scales shape the broad characteristics of climate and vegetation that support most fire regimes. An important control on millennial time scales is the long-term variations in the seasonal and annual cycle of insolation, because it influences the persistence and strength of the storm tracks, subtropical high-pressure systems, ocean-land temperature gradients, and ENSO variability, which in turn govern fuel composition (i.e., vegetation) and fire-climate on shorter time scales. For example, higher-than-present summer insolation in the early Holocene $(12,000$ to 6000 cal yr BP) supported long-term changes in vegetation and fire activity in the summer-dry Pacific Northwest, directly through its influence on higher-than-present summer temperatures and decreased effective moisture, and indirectly by enhancing atmospheric circulation systems that suppress summer precipitation (Bartlein et al. 1998; Whitlock et al. 2008; Anderson et al. 2008) and promote xerophytic fire-adapted vegetation (Long et al. 1998, Walsh et al. 2008). An increase in fire frequency occurred even in locations where the vegetation was held constant by infertile soil conditions (Millspaugh et al. 2000, Fig. 2). At the same time, summerwet regions experienced wetter conditions and fewer-thanpresent fires as a result of intensified onshore flow of moisture and more summer convection (Millspaugh et al. 2004; Brunelle et al. 2005, Anderson et al. 2008).

Long-term climate-fire linkages are evident on other continents as well. For example, higher-than-present annual insolation in the early Holocene may have been an important driver for the higher fire activity in southern South America (lat. 35-50S) that occurred then (Whitlock et al. 2007, Huber et al. 2004). Higher annual insolation is hypothesized to have weakened the westerlies at mid-latitudes resulting in 


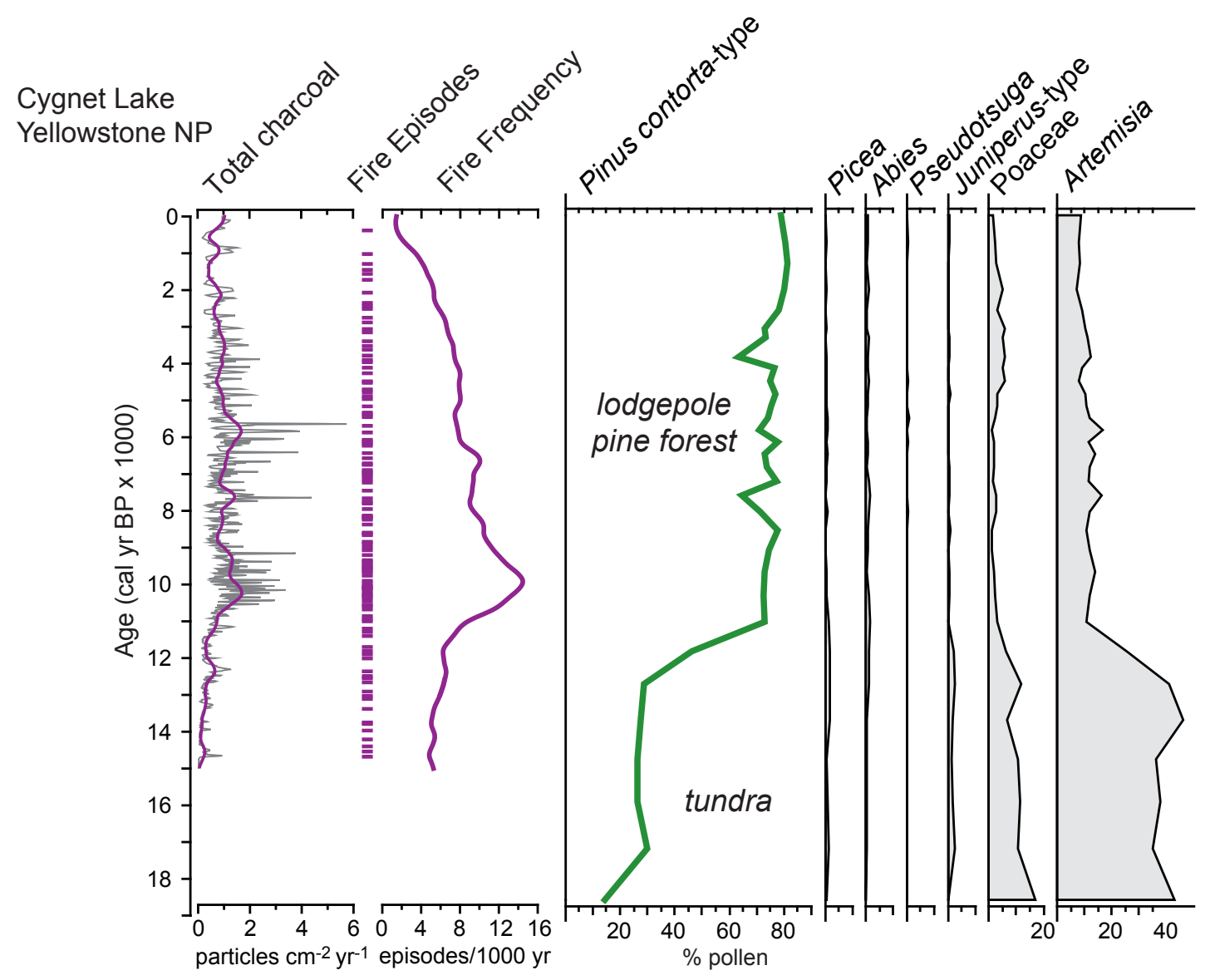

Fig. (2). Example of a high-resolution charcoal record and pollen data from Cygnet Lake, Yellowstone National Park (Millspaugh et al. 2000). Total charcoal influx (number of particles $/ \mathrm{cm}^{2} / \mathrm{yr}$ ) is developed by determining the charcoal concentration of large particles $(>125$ um diameter) in continuous centimeter intervals of the core and multiplying concentration by the sedimentation rate determined from a radiocarbon-based age model. Background trends show an increase at 11,000 cal yr BP, when the pollen data indicate a shift from tundra to forest. Positive deviations in charcoal above a prescribed threshold identify fire episodes (one or more fires during the time span of the sample), and these are used to calculate fire frequency. Notice that high fire frequency from 11,000 to 7000 cal yr BP, apparently driven by warm dry conditions, occurred even in the absence of vegetation changes at this site.

drier winters, earlier spring onset, and summer drought (Whitlock et al. 2007). At $6000 \mathrm{cal}$ yr BP, the fire patterns became more regionalized with high fire activity at low and high latitudes, and fewer fires at mid-latitudes. By $3000 \mathrm{cal}$ yr BP, fire regimes were spatially heterogeneous, reflecting vegetation differences, the strengthening of ENSO variability, and/or more anthropogenic burning. In eastern Canada, higher fire activity in the middle Holocene is attributed to insolation-driven drought. It was followed by lower fire activity in the late Holocene as summer insolation decreased (Carcaillet et al. 2002). In Australia and New Guinea, fire activity increased in the last 7000 years with the onset or strengthening of ENSO variability (Haberle et al. 2001).

Improved understanding of climate-fire linkages at regional and continental scales has motivated the development of the Global Palaeofire Database, housed at the University of Bristol (U.K.) (Fig. 3). This database of $>600$ charcoal records from lakes, wetlands, and soil has been used to examine global fire patterns over the last 21,000 years (Power et al., 2008), the role of fire in North
America at the end of the last glaciation (Marlon et al. 2009), and the changes in fire regimes over the last 2000 years (Marlon et al. 2008). Expansion of the global dataset, inclusion of fire as an interactive component of Earth Systems models (e.g., Thonicke et al. 2005), and rigorous data-model comparisons are underway or planned.

In summary, modern, historical, and paleoecological data suggest that fire-climate linkages are evident in individual records as well as regional and global compilations. Fireclimate is a response to the sum of climate variations occurring over multiple time scales ranging from seasons to millennia. On short time scales, anomalies in atmospheric circulation patterns prior to and during a fire season create conditions conducive for burning. These anomalies are often embedded in large-scale teleconnection patterns manifest on interannual and interdecadal time scales, which determine the probability of fire events and fire-event synchrony. On longer time scale, climate variations create, maintain, and change fire regimes through slowly varying atmosphereocean interactions and surface-energy feedbacks that shape regional fire-climate conditions and vegetation patterns. 


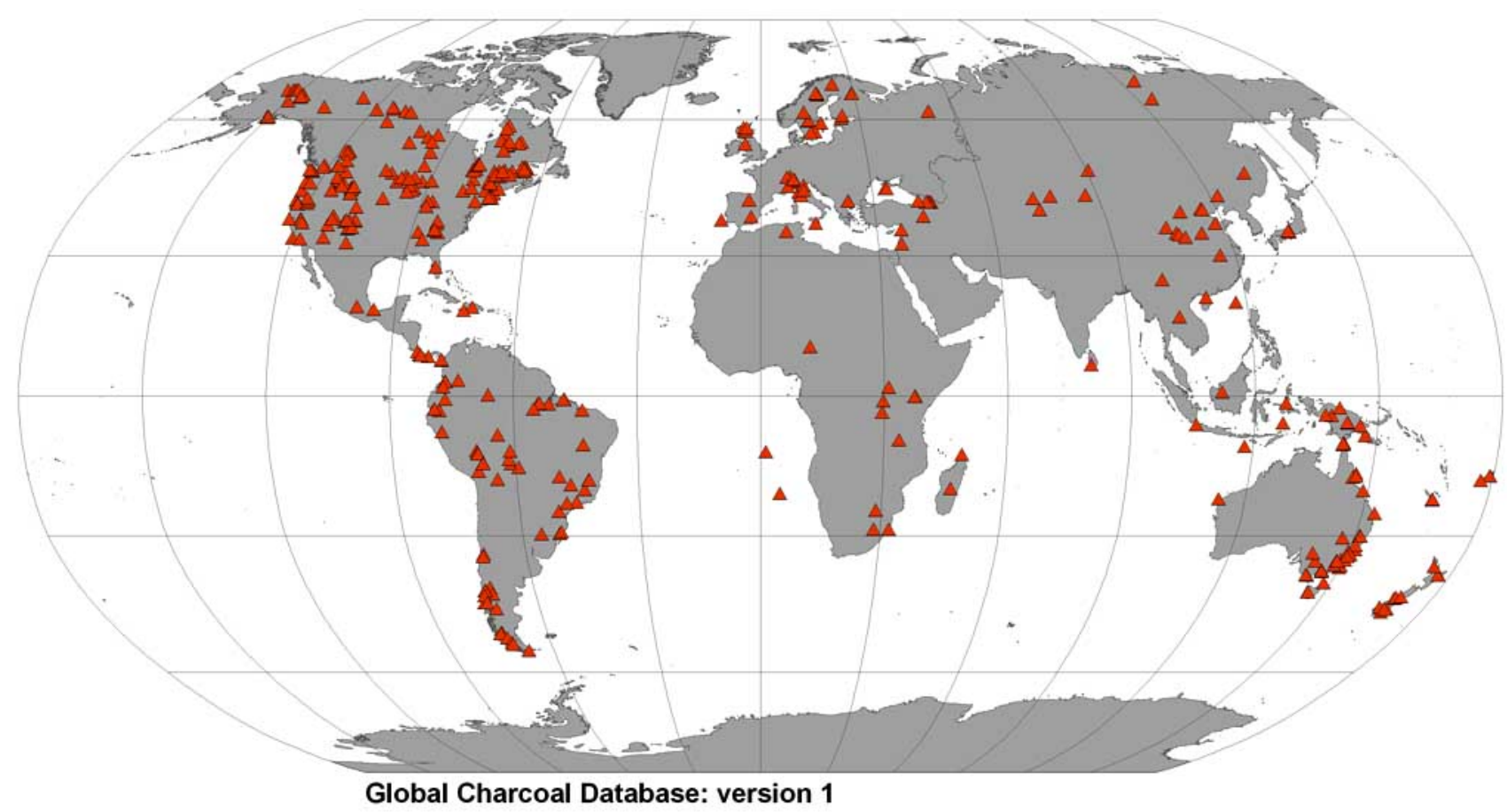

Fig. (3). Location of charcoal records in the Global Paleofire Database, BRIDGE, University of Bristol (U.K.) (provided by M.J. Power, May 2009) (http://www.bridge.bris.ac.uk/projects/QUEST_IGBP_Global_Palaeofire_WG). (Accessed 12/09).

Knowledge of fire-climate drivers on all time scales is necessary to better understand the temporal and spatial dimensions of current and future fire regimes (Flannigan et al. 2009, 2005, Bartlein et al. 2008, Trouet et al. 2006).

\section{FIRE-FUELS AND FIRE-VEGETATION LINKAGES}

Although fire and vegetation linkages are at least partially determined by weather and climate, the role of burnable biomass alone is important enough to warrant separate discussion. In general, fire characteristics are dictated by fuel composition, distribution, and moisture at short time scales and small spatial scales, and fire regimes are shaped by vegetation and climate on long time scales and large spatial scales (Fig. 1). Not surprisingly, statistical modeling of global fire patterns suggests that the distribution of fire is related to net primary productivity, because of the importance of burnable biomass. At regional and local scales, however, this simple relation becomes complicated by seasonal mismatches between ignition and fuel availability, even in high biomass regions (Krawchuk et al. 2009). For example, Pacific Northwest forests have ample biomass, but fuels are too moist during most fire seasons to burn. Only in exceptionally dry summers are large severe fires possible, e.g., in 2002 when the Biscuit Fire burned $2000 \mathrm{~km}^{2}$ in Oregon and California. In contrast, fireclimate conditions are suitable in most deserts and sparse shrublands, but discontinuous fuel cover has limited fire, at least prior to the spread of exotic flammable plant species.

At local-to-regional scales, the arrangement of fuel biomass strongly determines the frequency, size, and intensity of fire events by influencing fire spread and intensity. Strong environmental gradients give rise to heterogeneous fuel conditions, which in turn create complex fire patterns and fire histories over space and time (Heyerdahl et al. 2008, 2001, Veblen et al. 2000, Iniguez et al. 2008, Beaty and Taylor, 2008). For example, the complex mosaic of forests in northern California is ascribed to the elevational and substrate differences, environmental gradients, and topographic barriers that shape fire size and severity, as well as to the lasting legacy of previous fires on fuel conditions (Skinner et al., 2006, Taylor and Skinner, 2003; 1998). Throughout the Holocene, fire regimes in this region have been dynamic. From 11,000-4000 cal yr BP, patchy discontinuous forests on infertile substrates experienced high fire frequency, but from 4000-500 cal yr BP, these same areas maintained low fire frequencies as cooling led to the loss of the shrub understory component. Concurrently, areas underlain by more-fertile soils experienced an increase in fire frequency in the late Holocene as forests became more closed (Briles et al. 2008, 2005, Briles 2008). Both vegetation changes were driven by cooler wetter conditions in the late Holocene, but the nature of the change and its impact on fuels determined whether the shift resulted in more or less burning than before.

In south-central British Columbia, Gavin et al. (2006) showed that adjacent sites in the same climatic setting experienced different levels of fire activity during middleHolocene aridity. Frequent fires led to fuel differences that influenced the probability of subsequent fires. Only as the climate became wetter in the late Holocene did climatic controls override site-specific fuel differences as a driver of fire regimes. Similarly, in the northern Great Plains, Clark et al. (2002) described fuel-climate linkages in grassland fire regimes during two periods in the Holocene. During the middle Holocene (ca. $8000 \mathrm{cal}$ yr BP), a pronounced drought 
cycle of 100- to 130-years was detected, with dry phases associated with low grass production, high erosion, and few fires and wet phases associated with high grass production and increased fire activity. In the late Holocene (ca. $2800 \mathrm{cal}$ yr BP), fluctuations in grass abundance and fire activity were less pronounced as a result of a cooler, less variable climate. These studies underscore the fact that fire-fuel linkages on short-time scales cannot be understood without knowing the long-term relationship between vegetation and climate.

Fire history in Alaska also provides examples of how centennial- to millennial-scale vegetation shifts can amplify or dampen the direct influence of climate change on fire regimes. In northern Alaska, the development of birch shrub tundra (Betula glandulosa and/or B. nana), ca. 13,00014,000 cal yr BP, was associated with a distinct increase in fire frequency, from virtually no fire in the herb-dominated tundra prior to birch expansion to fires occurring on average every 140 years after birch expansion (Higuera et al. 2008, 2009). Although temperatures increased over this period, increased burning with the addition of birch implicates the new fuel source as a key element in facilitating fires. During the Holocene, changes in vegetation altered the fire regime in a direction that was opposite from what climate alone would have promoted. With the expansion of deciduous trees at ca. 10,000 cal yr BP, fire frequencies decreased despite increased summer warmth and drier conditions than at present (Higuera et al. 2009). During the late Holocene, after ca. $5500 \mathrm{cal} \mathrm{yr} \mathrm{BP}$, fire frequencies increased with the expansion of black spruce (Picea mariana), marking the development of the modern boreal forest (Lynch et al. 2003, 2004, Hu et al. 2006, Higuera et al. 2009). At millennial time scales, the development of boreal forest was associated with cooler wetter conditions than before, which would have limited fire occurrence. The addition of the black spruce, a highly flammable species, appears to have been sufficient to increase fire frequencies to modern levels (Brubaker et al. 2009).

Networks of charcoal and pollen data disclose the role of regional, continental and global changes in biomass over millennia. Marlon et al. (2006) compared the ratio of arboreal to nonarboreal pollen (AP/NAP), an indicator of woody biomass, with charcoal influx, an indicator of fire activity, at fifteen sites in the northwestern U.S. As forest cover increased in the last 12,000 years, so too did the overall levels of burning, implying a direct relationship between fuels and fire activity (Fig. 4). Charcoal levels increased to about $2000 \mathrm{cal} \mathrm{yr} \mathrm{BP}$ and then decreased, either as a result of climate cooling or increased anthropogenic burning in recent millennia. In a second study, Marlon et al. (2009) examined AP/NAP and charcoal influx in 35 lakesediment records from North America to detect evidence of changes in fire activity during the Younger Dryas cooling event (12,900-11,700 cal yr BP). Prior to Younger Dryas event, charcoal influx increased as conditions warmed and fuel biomass increased. At most sites, charcoal influx remained unchanged or dropped during Younger Dryas event and abruptly increased at the end of it. Increasing biomass at the late-glacial/early Holocene transition is thought to be a key driver of this last increase in fire activity. At the global scale, similar relations between fuel biomass and fire have been noted over the last 21,000 years (Power et al. 2008). For example, cool conditions during the last ice age resulted in sparse vegetation (low AP/NAP) and few fires (higher charcoal influx), whereas warmer conditions in the Holocene led to increased biomass and more fires.

Fuel and vegetation constraints on fire activity are not independent of climate, but rather serve as a set of bottom-up controls. At short time and small spatial scales, the abundance, structure, and moisture levels of fuels directly influence fire spread, size, and intensity. Over longer temporal and larger spatial scales, the complex interaction between climate and vegetation influences fuel distribution and flammability that, in turn, shape long-term trends in biomass burning. Given the distinct linkages between vegetation and fire regimes, both across the modern landscapes (Parisien and Moritz 2009, Krawchuk et al. 2009) and through time, the concept of a fire regime may be best defined by the full range of variability in fire activity within a given vegetation type, over the period of its existence. Such a long-term perspective (the super-fire regime of Fig. 1) inherently incorporates variability from shorter-term fluctuations in climate and fuels (i.e., the smaller fire triangles), and arguably provides the best description of the type of fire patterns that a single biome can (or cannot)

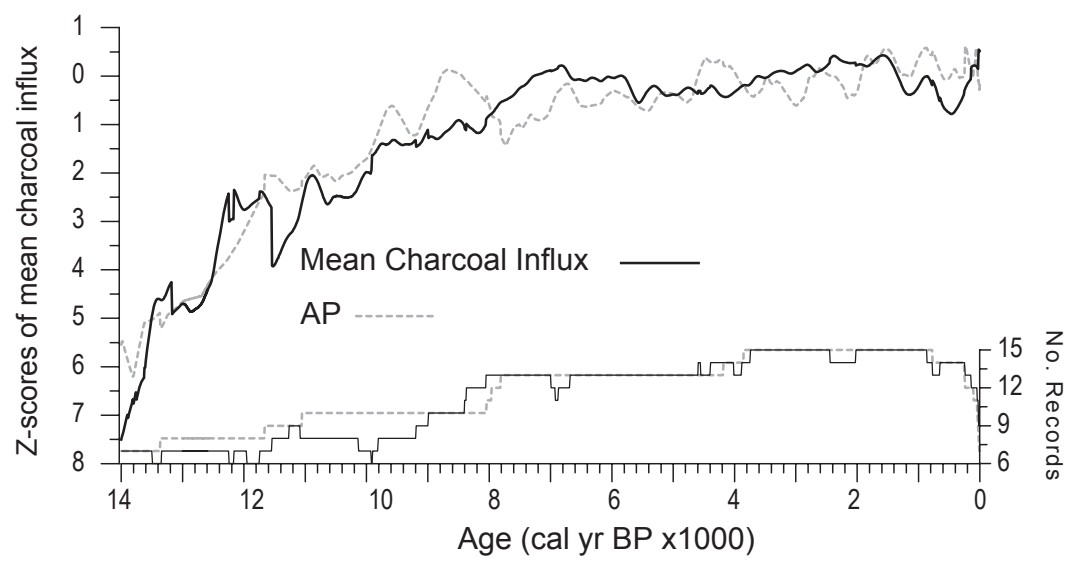

Fig. (4). Late-glacial and Holocene trends in biomass burning based on the smoothed mean of standardized records of charcoal influx (black line) and changes in available fuel biomass based on arboreal pollen percentages (AP, gray dashed line) (after Marlon et al., 2006). The data come from 15 northwestern U.S. records. The number of records that make up the mean at any given time is plotted below the mean trends. Note that the increase in charcoal influx tracks the rise in forest cover and available fuels, indicated by rising AP. 
maintain. It expands our understanding of the modern geography of fire to include conditions that are different than present and possibly even novel (e.g., Williams et al. 2007). This expanded perspective, in turn, becomes valuable when contemplating changing fire regimes under future climate scenarios.

\section{HUMAN-FIRE LINKAGES}

Humans have influenced fire regimes for thousands of years through their impacts on ignition rates, fuels, and land cover (Bowman 2009, Archibald et al. 2009, Nevle and Bird 2008, Storm and Shebitz 2006, Ferretti et al. 2005, Miller et al. 2005, Bond et al. 2005, Ruddiman 2003, Pyne 2001, Denevan, 1992, Parisien and Moritz 2009). These changes, in turn, have had dramatic impacts on ecosystem structure, including large-scale shifts in the dominant successional pathways and the amount of woody biomass present on the landscape. Paleoecological research suggests that the influence of humans on prehistoric fires in many regions was primarily localized, governed by population density, human settlement, and land use. At small spatial scales, humans have altered fire activity by igniting fires when and where they were naturally rare, by extending the fire season, and by suppressing or eliminating fires.

The influence of anthropogenic burning depends on the natural controls of fire activity summarized in the fire-behavior triangle (Fig. 1). The influence is greatest in biomes where natural ignitions are infrequent, where fuel modifications effectively increase flammability of vegetation, and where climatic variations provide weather conducive for ignition. For example, rainforests experience few fires because of high fuel moisture levels and limited lightning ignitions, whereas desert biomes have limited fire activity because of sparse and discontinuous fuels. Thus, climate acts to suppress fire in fuel-rich rainforest biomes, and fuel availability limits fires in xeric scrub and desert biomes. At both of these extremes, human actions probably have had little impact on natural fire regimes and vegetation at regional scales (Fig. 5).

Where climate and fuel conditions are less extreme, humans may have enhanced fire-weather and fuel flammability in ways that overcome natural limitations to burning and cause wholesale switches in biome types (Fig. 5a). Hence, dry forests with adequate fuels and seasonal climates and grasslands with continuous fine fuel cover are more sensitive to human influences because humans can focusing ignitions and fuel manipulations during times when fire-weather is most acute. Likewise, fire suppression in grasslands has led to the expansion of woodlands, and fire suppression in dry forests has shifted fire regimes from small, frequent, low-severity fires to large less-frequent, severe fires. Grazing also reduces the amount and continuity of fine fuels which, depending on its intensity and setting, can increase fuel biomass or reduce it, thereby facilitating a shift to scrubland or desert conditions. Examples of prehistoric human impacts in three different settingsstrongly climate-limited fire regimes, strongly fuel-limited fire regimes, and fire regimes where fuels and climate interact-help illustrate these relationships and suggest that human impacts on natural fire regimes are strongest where high population densities and cultivation coincide.

Tropical, subtropical and temperate rainforests are examples of climate-limited fire regimes, where fires are infrequent as a result of wet fuels and few ignitions or where a mismatch occurs between the timing of ignitions and low fuel moisture (Cordeiro et al. 2008, Bush and Silman 2007, Bush et al. 2007, Deneven 2003, Meggers 2003, Mayle et al. 2000, Bush et al. 2000). The probability of biome switching as a result of human-set fires is low in such settings, because wet conditions and low fuel flammability generally override the influence of human ignitions and fuel manipulations. Nonetheless, repeated burning opens the forest, dries fuels, and enhances the impact of subsequent fires (Cochrane and Barber 2009, Thompson et al. 2007, Cochrane 2003, Cochrane et al. 1999, Uhl and Kauffmann 1990). The conversion of forest to grassland via shifting cultivation practices in subtropical forests today suggests that biome switching in the past would have been feasible where human populations were sufficiently large or concentrated (Styger et al. 2007, Lawrence 2004, Nepstad et al. 2001). Research suggests that the impact of prehistoric fires in wet rainforests was mostly localized to areas of dense human settlements associated with terra preta (soils indicating human occupation), terra mulata (soils indicating cultivation), and introduced agricultural crops (Cordeiro et al. 2008, Bush and Silman 2007, Bush et al. 2007, Heckenberger et al. 2007). Widespread biomass burning and alteration of vegetation at large scales have been described along the Amazon River and its tributaries where terra preta and terra mulata soils are abundant (Heckenberger et al. 2007). In fact, it has been suggested that past periods of burning in these areas may have influenced atmospheric concentrations of carbon dioxide and methane at global scales (Nevle and Bird 2008, Ferrati et al. 2005).

Aside from major riverways, however, the impact of anthropogenic burning on tropical/subtropical forests appears to have been limited, probably because human ignitions and efforts to dry fuels through fuel preparation or repeated burning were overcome by strong climatic controls (Bush and Silman 2007). In the Peruvian Amazon Basin, Bush et al. (2007) compared fire and vegetation histories from four lakes. Using introduced agricultural pollen taxa as a surrogate for human presence, they found that fire activity increased locally when large levels of nonnative pollen types and archeological data indicated human presence and settlement. Few changes in fire activity occurred at sites more distal to human settlement $(>15 \mathrm{~km})$. They concluded that, in rainforest ecosystems, evidence for settlement was associated with increased fire activity yet the impacts were constrained spatially by climate and fuel conditions.

Although fires are less climate-limited in temperate forests, research there also suggests that climate has been the primary driver of fire and vegetation change throughout the Holocene, except where human settlement influenced fire and vegetation locally. In forests of the northeastern U.S., Clark and Royall $(1995,1996)$ found that prehistoric humanset fires rarely impacted fire regimes and vegetation at regional scales. A network of charcoal records across a gradient of land-use intensity revealed that variations in fire 


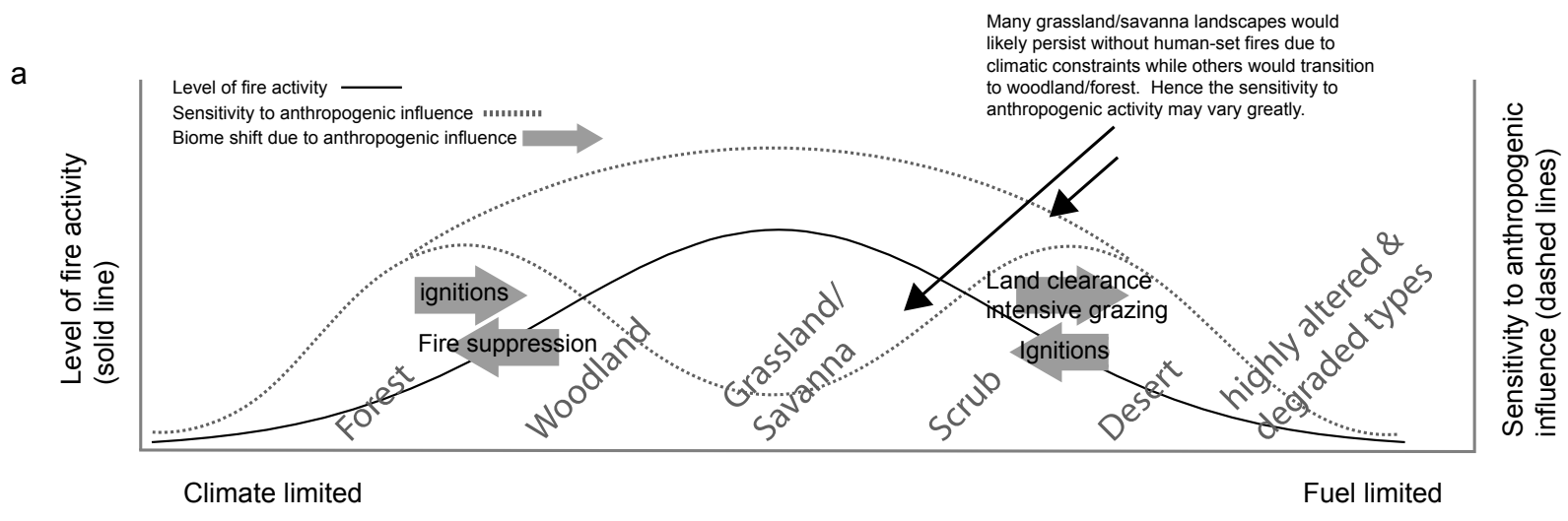

b

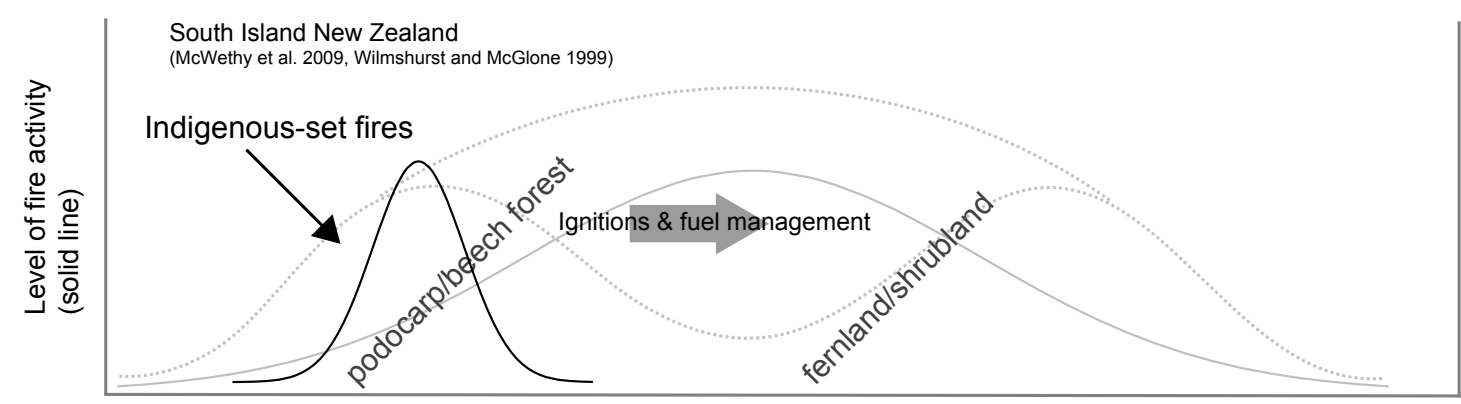

Climate limited

Fuel limited

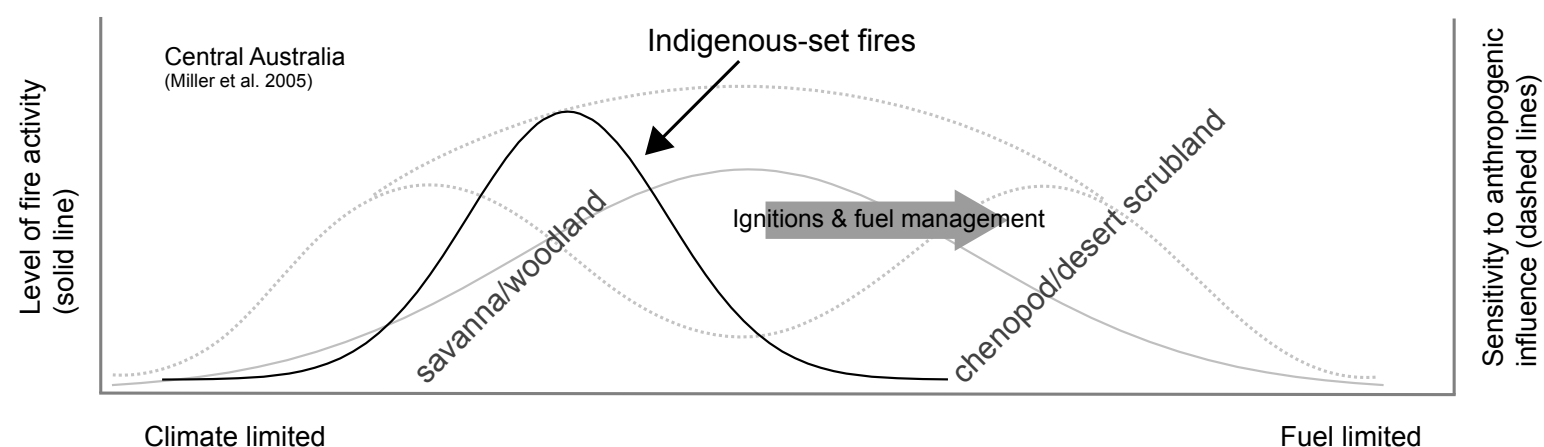

d

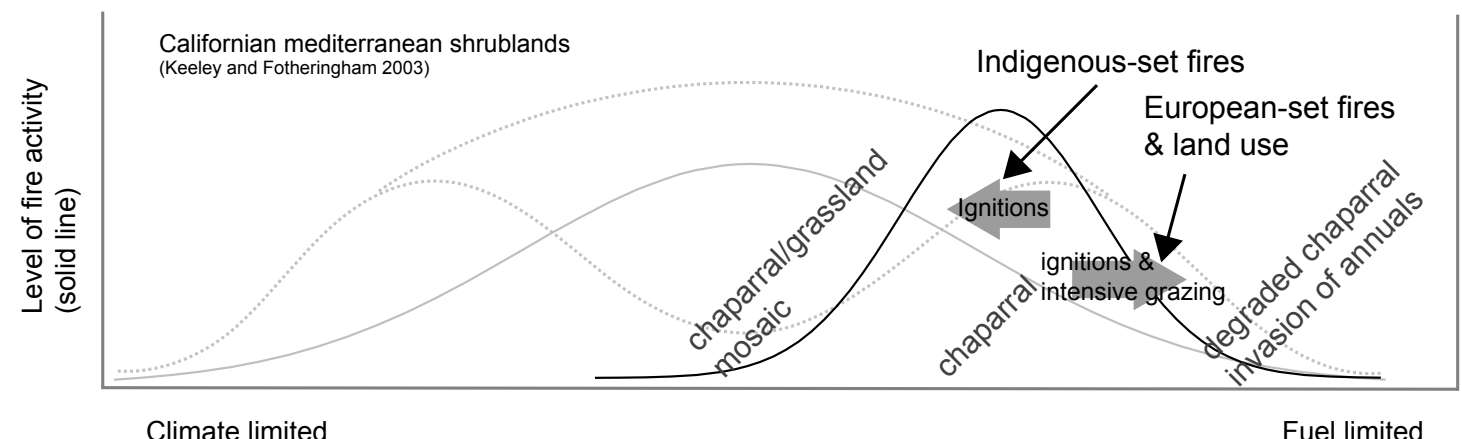

Climate limited

Fuel limited

Fig. (5). Anthropogenic influences along a gradient of climate-limited to fuel-limited fire regimes. a. in low- and mid-latitudes where a gradient from forest to desert exists. (Solid line represents levels of fire activity associated with different biomes. Dashed line indicates the degree to which these biomes are sensitive to biome switching as a result of human impacts on fire regimes (e.g., ignitions, fuel management, fire suppression, land use)); b. on South Island New Zealand, following the arrival of people, ca. 700 cal yr BP; c. in Australia, ca 45,00050,000 cal yr BP, with arrival of people; and d. in California mediterranean scrubland pre- and post-Euroamerican settlement. See text for discussion. 
activity primarily tracked changes in climate. Archeological and ethnographical data from forest regions of the northeastern U.S. provide additional support for localized impacts, suggesting frequent use of fire and associated conversion of vegetation near Native settlements (Russell 1983). Whitlock and Knox (2002) compared Holocene environmental histories and archeological records in the Pacific Northwest and found that the vegetation and fire history tracked large-scale changes in climate while human influences on fire regimes and vegetation were evident at smaller spatial scales. Widespread changes in the forest history of central Europe and southern Scandinavia also point to climate as the primary driver of vegetation change, with humans acting as a secondary control at smaller scales by setting and suppressing fires. Bradshaw and Lindbladh (2005) described a complex interaction between past changes in climate, fire, and human activity in southern Scandinavia where human-set fires may have amplified the expansion and decline of key forest species (Fagus sylvatica and Picea abies) and conclude that climate was clearly the primary driver of Holocene vegetation dynamics at large scales. Examining pollen data from a raised bog in central Europe, Wehrli et al. (2007) argued that human-set fires may have helped regulate the movement of key forest species (Abies alba and Fagus silvatica) and facilitated heterogeneity and diversity of forests during the middle and late Holocene, especially where human settlement was concentrated. Carcaillet et al. (2007) found that changes in fire frequency in the boreal forests of Sweden during the Holocene were best explained by variations in climate, but beginning with the $19^{\text {th }}$ century, fires were also directly associated with landcover changes. Other studies from Scandinavia and Europe (e.g., Valsecchi et al. 2008, Tinner and Lotter 2006) provide further support that human influence on fire regimes and vegetation was mostly local.

The preponderance of examples documenting major shifts in vegetation and permanent biome switching from human-set fires comes from island environments. In these settings, ignitions and suitable fire-weather are often limiting, and human actions can override climate by focusing ignitions to periods of fire-conducive weather. Research examining the long-term fire and vegetation history of islands in the Pacific Basin (e.g., Rapa Nui, New Zealand, Mangaia) show that human arrival was followed by an increase in fire activity, deforestation, land clearance and cultivation of plant crops (Kirch and Kahn 2007, Anderson 2002, McGlone and Wilmshurst 1999, Kirch 1996). In South Island, New Zealand, human arrival 700 years ago was accompanied by an initial period of burning and deforestation even in places where there was no evidence of cultivation (McWethy et al. 2009, Hamel 2001). The abrupt loss of New Zealand's forest occurred in the seeming absence of climate change and resulted in extensive erosion, loss of nutrients, and changes in lake chemistry (McWethy et al. 2009, unpublished data (Fig. 5b). New Zealand offers one of the best examples of human activity overcoming strong climate constraints on fire activity through deliberate and repeated burning (Ogden et al. 1998).

Africa and Australia provide examples of human impacts in climate-limited fire regimes from continental settings and human-set fires resulting in major shifts in vegetation. Western Uganda underwent widespread deforestation ca.
1000-1100 AD, coinciding with human immigration, settlement, and cultivation (Lejju et al. 2005, Ssemmanda et al. 2005, Taylor et al. 1999, 2000). Paleoecological records suggest that increased fires led to landscape-scale deforestation and cultivation of introduced food crops and cattle grazing permanently altered vegetation and natural fire regimes. In south-central Australia, Miller et al. (2005) examined carbon isotopes of emu eggshells to infer changes in diets over the past 140,000 years. They suggest that the timing and frequency of human-set fires may have led to a switch in biomes from savanna to chenopod/desert scrub (Fig. 5c). Supporting evidence comes from eastern (Turney \& Hobbs 2006), southeastern (Tibby et al. 2006), and northeastern Australia (Kershaw et al. 2007, Haberle \& David 2004, Turney et al. 2001), where sediment records show large increases in charcoal coinciding with intensification of human activity and increased climatic variability. Bird et al. (2008) note that present-day Aboriginal use of fire in western Australia promotes floral and faunal diversity at smaller scales than would occur naturally under a fire regime controlled by lightning. Importantly, they found that the impact of recent fires was mostly localized around residential camps and proposed that prehistoric fires would have led to similar patterns of burning. This observation challenges the hypothesis that Aboriginal fires resulted in anthropogenic landscapes at large spatial scales. Elsewhere in Australia and Africa, the interaction between human and climate controls of fire and vegetation is more complicated yet climate is assigned the primary role in shaping Holocene fire regimes at large spatial and temporal scales in many studies (Gillson and Ekblom 2009, Black et al. 2007).

Examples of human impacts in fuel-limited fire regimes come from desert and shrubland as well as chaparral, where spatial variability in fuels often leads to a mixed fire regime ranging from frequent low-intensity to infrequent highintensity fires. In the deserts and shrublands of the American Southwest, fuel-limited fire regimes are paced by ENSO variability, which alternates the development of fine fuels in warm (wet) El Niño years and fuel desiccation and fireconducive weather in subsequent cold (dry) La Niña years (Swetnam and Betancourt 1998). Fire regimes in such settings have been strongly altered by the loss of fine fuels from livestock grazing and active fire suppression, and these synergistic disturbances have led to vegetation conversion to desert and shrubland (Keeley and Fotheringham 2003). Paleoecological data from the region suggest that anthropogenic influences on fires and vegetation were primarily localized although the consequences were great where human settlement was concentrated (Allen 2002). Chaparral regions in southern California have steep environmental gradients, and as a result, area burned in any decade is highly variable (1-50\%, Keeley and Fotheringham 2003). Closed-canopy chaparral is almost impenetrable and would have offered few resources to Native Americans who have lived in the region for at least 10,000 years. Burning chaparral would have enhanced habitat for game animals, facilitated seed bulb and fruit production, increased water resources, reduced hazards, and improved travelways. Areas of high prehistoric population density show higher fire frequency at present than would be expected under natural conditions (Keeley 2004). Heightened burning would have 
altered vegetation from a landscape dominated by chaparral to a mosaic of chaparral/grasslands (Fig. 5d).

Grasslands and savanna biomes represent settings where fuels and climate interact to create fire regimes, because fuels are naturally ample and climate conditions are conducive to frequent fires. The evolution of grasslands is attributed to Late Cenozoic climate conditions that promoted fires in some areas (Retallack 2001) and to human use of fire in others (Archibald et al. 2009). Biome model simulations that eliminate fire show that many grassland and savanna environments would be forested in the absence of fire (Bond et al. 2005). The implication from these studies is a highly variable role for anthropogenic fires in grasslands and savanna. In fuel-limited systems with frequent natural ignitions, anthropogenic fires may have made little difference to the natural fire regime, whereas in wetter moreproductive grassland and savanna systems, deliberate burning may have prevented natural succession to forests. In Africa, the idea that humans played an important role in the evolution of grasslands is popular (Burchard 1998), yet pollen records show the existence of grasslands before human presence in some areas (Archibald et al. 2009, Scott 2002), and shifts between grassland and forest are closely tied to past climatic changes (Gillson and Ekblom 2009, Ekblom 2008). There is little evidence to suggest that human-set fires resulted in extensive biome switching in African savannas, although it is difficult to separate the relative influence of human activities and climate in biomes where fires are naturally frequent.

Guyette et al. (2002) suggest that population densities strongly regulate fire regimes and their impact on vegetation, and compare changes in fire activity during four stages of settlement history in the south-central U.S.: (1) 1650-1850 $\mathrm{AD}$, an ignition-dependent stage associated with low population densities where increased population led to increased fires; (2) 1850-1890 AD, a fuel-limited stage where human-set fires and land-use reduced the availability fuels, constraining fires; (3) 1890-1940 AD, a fuelfragmentation stage where land-use patterns affected the continuity of fuels, reducing fires; and (4) a culturedependent stage associated with mid- and late- $20^{\text {th }}$ century fire suppression. During most of the Holocene, human population densities were well below those of any stage described by Guyette et al. (2002), and prehistoric fire effects were highly localized. As population densities increased, wholesale conversion of vegetation through fires and land clearance occurred at large scales. This period was often followed by reduced avail-ability and fragmentation of fuels and, eventually, fire suppression.

Climate and land-use interactions on fire regimes are also evident at a global scale (Marlon et al. 2008). A comparison of late-Holocene charcoal records from around the world shows that fire activity was generally declining as a result of climatic cooling in the last 4000 years. Burning levels increased globally in the $18^{\text {th }}$ century and reached maximum levels by $1870 \mathrm{AD}$. This increase is attributed to human use of fire in forest clearance. After $1870 \mathrm{AD}$, fire activity decreased in all regions except the northern high latitudes, and the decline is explained by fuel limitations related to grazing and landscape fragmentation, as well as fire elimination. This last period is best described by Guyette et al. (2002)'s stages 3 and 4 of human influence on fires.

In summary, the potential for human activity to change fire regimes depends on the strength of the natural controls on fire, namely, climate and fuel. Humans most readily influence fire regimes by increasing the synchrony between ignitions, fire-weather and fuel conditions in time and space. In biomes where climate or fuel are not limiting, the lack of coincidence in ignitions, fuel flammability and fire-weather results in a small number of fires that are limited in size and ecologically insignificant. In such settings, humans have the greatest potential to influence fire regimes by focusing ignitions during weather conducive to fire, burning repeatedly, and increasing the flammability of fuels through fuel treatments. Focused and deliberate human-set fires during prehistoric times may have resulted in irreversible switches in biomes; however, in most settings the effects seem to have been localized. Presently, large human populations are facilitating widespread alteration of fire regimes and vegetation, even in settings where climatic limitations on fire are strong. In the Amazon Basin, Indonesia and Madagascar, repeated burning of rainforests is causing lasting conversion of forest biomes to grasslands (Cochrane and Barber 2009, Styger et al. 2007, Lawrence 2004). Just as climate and fuel drivers can change quickly relative to the time scale of a fire regime, so too can human drivers. Incorporating anthropogenic influences thus becomes a strong motivation for modifying most definitions of a "fire regime".

\section{TEMPORAL SCALING OF FIRE REGIMES}

The importance of spatial scale in the definition of fire regimes has long been recognized from a methodological perspective (Baker 1989a, Agee 1993, Morgan et al. 2001) and in research focused on landscape equilibrium theory (Sprugel 1976, Turner et al. 1993 a,b), reserve design (Baker 1989a), and climatic change (Clark 1989, Sprugel 1991, Whitlock et al. 2003). Early work on disturbances considered their spatial and temporal patterns and how these affected vegetation dynamics and ecosystem properties (e.g., Heinselman 1973). Subsequently, it was recognized that forest disturbances create a steady state in some regions, e.g., waves of dead Abies tree in subalpine forests of New York State (Sprugel 1976), whereas elsewhere, large and/or infrequent disturbances preclude the possibility of steadystate conditions, e.g., in crown-fire-dominated forest ecosystems (Romme 1982, Baker 1989b, Turner and Romme 1994). The conceptual model that explains landscape dynamics of disturbances (Turner et al. 1993b) explicitly includes both space and time, but the temporal dimension is only considered relative to the impacts of disturbances on vegetation (i.e., recovery time), rather than the drivers of disturbance regimes themselves.

Characterizing disturbance regimes and their controls in a manner that explicitly integrates information from many spatial scales is an area of active research (e.g., Niemi et al. 2000; Falk et al. 2007). By quantifying how fire frequencies change at increasingly large spatial scales, the event-area relationship reflects mechanisms that are non-stationary in space, such as landscape connectivity. If fire sizes are large 
and the landscape is homogenous, then fire frequencies will change little as greater areas are considered; in contrast, if fires are small and burn in heterogeneous patches, then fire frequencies will vary greatly at different spatial scales. The parameters of the event-area relationship thus vary between different landscapes and provide a multi-scale metric with mechanistic interpretations linked to the climate and fuel drivers of a fire regime. This type of cross-spatial scale analysis of fire regimes has both theoretical value and practical application. For example, by explicitly quantifying the degree to which fire frequencies are scale dependent, researchers and managers do not have to apply a single mean fire return interval (FRI; years between fires) to describe or manage a landscape but instead can consider fire activity simultaneously at multiple scales. Additionally, the crossscale metric provides a tool for detecting changes in fire regimes, either in the past or future that could otherwise be obscured when focusing on a single spatial scale (Falk et al. 2007).

In comparison, cross-temporal scale analysis has received little attention. Tree-ring and lake-sediment records provide one of the only means for addressing a number of key questions: (1) What temporal scales define a fire regime? (2) At what temporal scales have fire regimes changed in the past, and how do these compare with the temporal variability of fire drivers (e.g., climate, vegetation change)? (3) Are there biomes where the concept of a fire regime is not useful, given variability in fire controls, and if so, how can we modify the concept of a fire regime to retain its theoretical and applied value?

In many ecosystems, fire-regime characteristics only emerge after many decades or centuries, even when large spatial areas are taken into account. For example, in a subalpine or boreal forest, where a stand may burn every one to several centuries (Johnson 1992, Agee 1993, Baker 2009), observational records are far too short to define the sitespecific characteristic timing, size, or severity of fires. In contrast, a similar area in a grassland or shrubland ecosystem may burn multiple times in a decade, and observations may provide an adequate sample size to estimate mean FRI and other statistical properties. Because the statistical properties of fire behavior and fire effects in most forests cannot be accurately estimated without long time series, fire-history reconstructions based on tree-ring and sediment-charcoal records become essential.

At any given site, as the length of a fire-history record increases, fire events are accumulated at a rate dependent upon the average rate of burning (i.e., the $b$ parameter of a Weibull model, which is directly related to the mean FRI; Grissino-Mayer 1999), and random variability, if the controls of a fire regime are unchanging (Fig. 6). Estimates of the mean and variance of FRIs become increasingly accurate and precise as a record lengthens. The metric $t_{\text {stable }}$ defines the shortest time span where the standard deviation associated with the mean FRI varies less than $5 \%$ when one additional fire is sampled (Fig. 6a). Although increasing the temporal length beyond $t_{\text {stable }}$ would increase the precision of the estimated mean FRI, $t_{\text {stable }}$ defines an acceptable level of precision for the mean FRI. Conceptually, a specific $t_{\text {stable }}$ exists for any metric of a fire regime we might consider. Intuitively, $t_{\text {stable }}$ increases as the rate of burning in a system decreases, such that it requires 5-8 times as many years as the mean FRI to reach $t_{\text {stable }}($ Fig. 6b). Patterns at time scales shorter than $t_{\text {stable }}$ primarily reflect random variability (Lertzman et al. 1998), and estimating the mean FRI with a record shorter than $t_{\text {stable }}$ leads to an overestimate of fire frequency (Finney 1995).

The relationship between the mean FRI and $t_{\text {stable }}$ has two important implications that link to similar scaling issues in landscape ecology. Methodologically, it is impossible to accurately quantify a fire regime with one dataset signi-

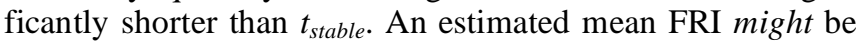
accurate, but it will not be precise, i.e., the estimate may be close to the true mean FRI but associated with large confidence intervals. Consequently, it is difficult to identify one fire regime as distinct from another (whether in space or time) when the mean FRI is long, relative to the length of the dataset. This issue can be overcome by sampling larger areas, in the same way that space-for-time substitutions are utilized in shorter-term fire-history studies (e.g., atlas or treering-based fire-history studies: Romme 1982, Morgan et al. 2001, Kasischke et al. 2002). Traditionally, a unique advantage of paleoecology has been to free ecologists from the assumption of spatial homogeneity that is implicit in space-for-time substitutions (e.g., Fastie 1995). In the context of fire regimes, recent paleoecological work has utilized both time-for-space and space-for-time analogies to provide more precise fire-history records in systems with long fire-return intervals. For example, Gavin et al. (2006) pooled FRI estimates from two records within $10 \mathrm{~km}$ of each other to reconstruct the late-Holocene fire history in subalpine forests of British Columbia. Higuera et al. (2009) pooled FRIs from three sites from boreal forests in northern Alaska. In each case, pooling multiple millennia of firehistory data across space (i.e., space-for-time analogy) was critical for quantifying fire regimes and detecting changes in relation to climate and vegetation change.

Conceptually and practically, if fire occurrence is sensitive to climate and vegetation changes that vary significantly on time scales shorter than $t_{\text {stable, }}$, then a fire regime may never have the "opportunity" to develop. This would be particularly true in systems that are characterized by large infrequent fires (e.g., "stable, very high variance" systems, sensu Turner et al. 1993b). In such a scenario, the landscape pattern observed or reconstructed does not describe a current fire regime, but rather represents an artifact of a partiallydeveloped fire regime from the past (Sprugel 1991). For example, if it takes 1000 years for a fire regime with a 200yr mean FRI to develop (Fig. 6b), then climate changes lasting 400 years (e.g., the Medieval Climatic Anomaly, 9001300 AD) may not be detectable or ecologically meaningful in an ecosystem, even though the climate change truly altered the probability of fire. If climate continually shifts on time scales shorter than $t_{\text {stable, }}$, then a given fire regime may never fully develop, and the concept of a stable fire regime is not applicable. Because these scenarios also include a spatial component, addressing questions of this nature requires a combination of paleoecological and landscape-ecology approaches to overcome the high variability inherent in many fire regimes. Even then, however, it may be impossible to separate a signal of change from the noise of variability, particularly over short time scales. 

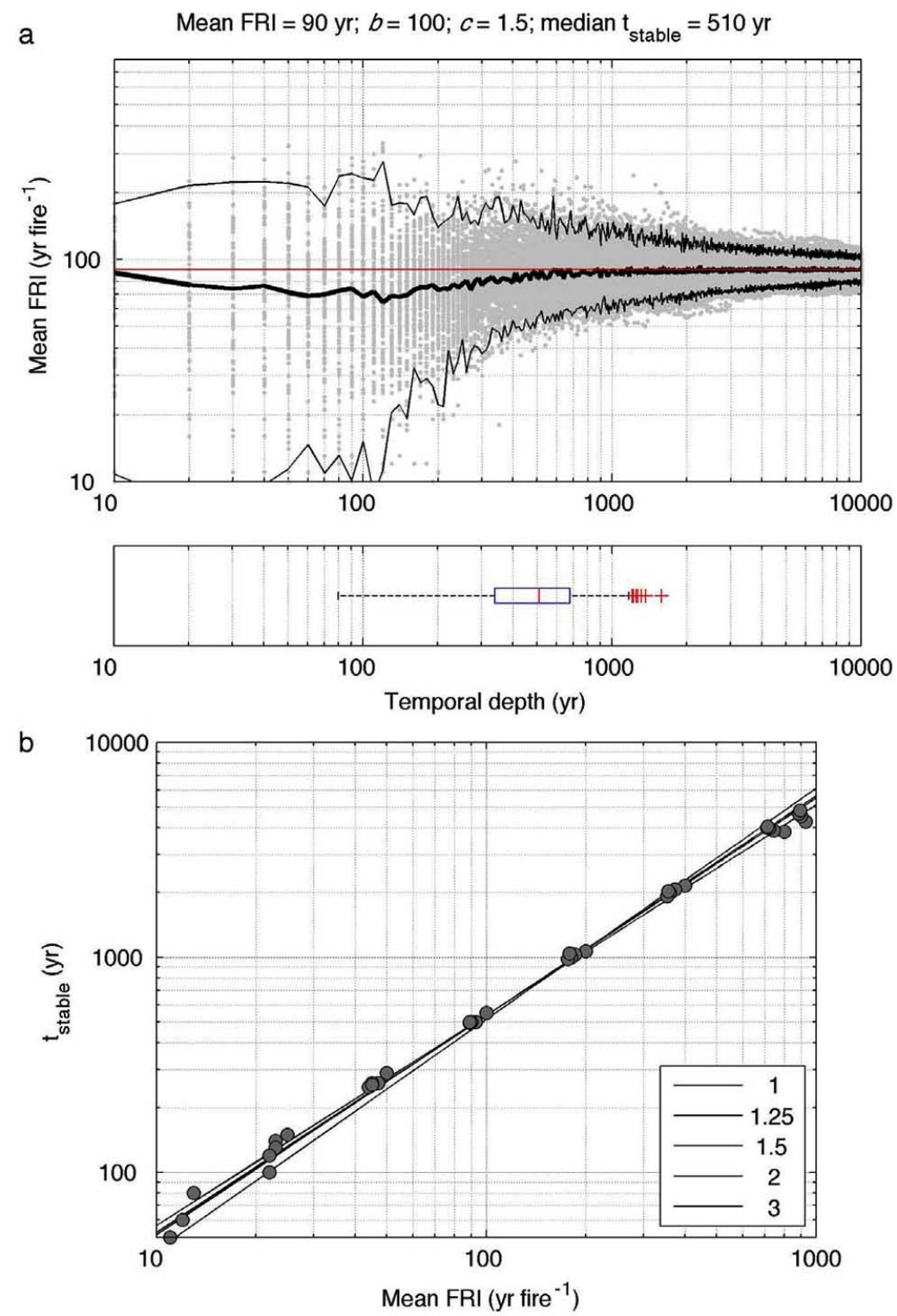

Fig. (6). Accuracy and precision of estimated mean fire return interval (FRI) from simulated fire-history records. a. Mean FRI as a function temporal depth of samples (gray dots), based on 1000 simulations from a fire regime defined by a mean FRI of $90 \mathrm{yr}$ (red horizontal line) and Weibull $b$ and $c$ parameters of $100 \mathrm{yr}$ and 1.5 (unitless). The average, $2.5^{\text {th }}$ and $97.5^{\text {th }}$ percentiles of the mean FRI at each point on the x-axis are represented by the thick and think black lines. The temporal depth (yr) at which the standard deviation of FRIs changes by less than 5\% when one sample is added to the series, $t_{\text {stable }}$, from each of the 1000 simulations is identified in the box plot $\left(10^{\text {th }}, 25^{\text {th }}, 50^{\text {th }}, 75^{\text {th }}, 90^{\text {th }}\right.$ percentiles, and outliers). The median $t_{\text {stable }}$ from these simulations is 500 years, indicating the most common time span required to obtain an accurate (i.e., close to the red line) and precise (narrow confidence intervals) estimate of the mean FRI. b. $t_{\text {stable }}$ values as a function of the mean FRI from for eight different Weibull b parameters and five different Weibull c parameters (for a total of 45, 1000-yr simulations). $t_{\text {stable }}$ scales directly with the mean FRI (when plotted on log-log axes).

Paleofire records not only help define fire regimes by providing the necessary data to estimate a mean FRI (and other statistics), but they are poised to uniquely highlight the mechanisms and time scales over which fire regimes exist and change. In so doing, long-term fire-history data should add significantly to our understanding of the hierarchical nature of the fire triangles. For example, it is conventional to summarize millennial-scale fire history in terms of fireepisode frequency, defined at one or several time scales (e.g., 500-, 1000-, or 2000-yr; Long et al. 1998, Gavin et al. 2006, Whitlock et al. 2008). These summaries highlight variability over time, but they can obscure patterns at longer and shorter time scales. Similar to analyzing fire regimes across multiple spatial scales (Falk et al. 2007), analyzing fire regimes across multiple temporal scales reveals cross-scale patterns that will ultimately improve our understanding of fire regimes and their controls.

The interactive influences of climate and vegetation on Holocene fire regimes change over multiple temporal scales, and this is evident when considering the scale of changing fire frequencies. For example, in Alaska, the increase in fire frequency at ca. $5000 \mathrm{cal} \mathrm{yr} \mathrm{BP,} \mathrm{associated} \mathrm{with} \mathrm{the} \mathrm{increase}$ 

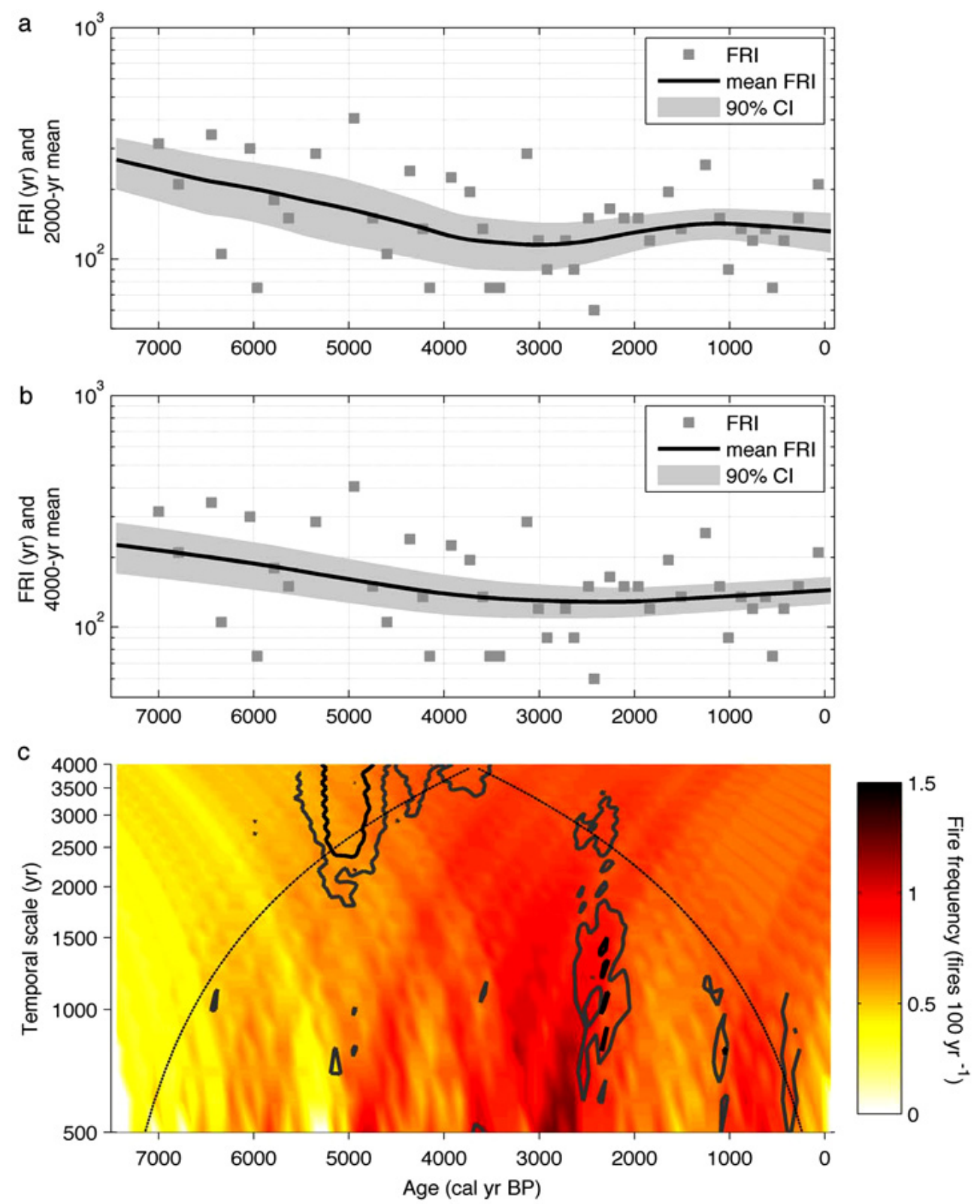

Fig. (7). Mean and raw fire return intervals (FRI) inferred from sediment-charcoal data from Code Lake, Alaska (Higuera et al. 2009) and summarized at different temporal scales. a. Raw FRI values (gray boxes) and the 2000-yr smoothed (thick black line) mean FRI, with $90 \%$ confidence intervals (CI; gray envelope); b. Same as a. but with a 4000-yr smoothed mean; c. Multi-scale fire frequency (fires $100 \mathrm{yr}^{-1}$ ) from Code Lake, based on the same fire dates as illustrated in $\mathbf{a}$. and b. Darker reds represent higher fire frequencies and lighter yellows represent lower fire frequencies, respectively, at the temporal scale identified on the y-axis. Light gray and black lines outline areas in x-y space where FRI distributions for periods $y$-yr before and after are significantly different at the alpha $=0.05$ and 0.01 levels, based on an AndersonDarling test, i.e., these areas identify change points in the fire record. In this case, when summarized at $2000-4000 \mathrm{yr}$ intervals, fire frequencies increased significantly around $5000 \mathrm{cal} \mathrm{yr} \mathrm{BP;} \mathrm{when} \mathrm{summarized} \mathrm{at} \mathrm{1000-3000} \mathrm{yr} \mathrm{time} \mathrm{scales,} \mathrm{fire} \mathrm{frequencies} \mathrm{decreased}$ significantly around $2300 \mathrm{cal} \mathrm{yr} \mathrm{BP}$. Due to multiple comparisons and the a posteriori nature of this analysis, isolated areas of statistical "significance" are not considered meaningful.

in black spruce, was followed by multi-centennial and shorter time scale changes in fire frequency at 2300, 1000 and 400 cal yr BP (Fig. 7). Following increased fire frequency ca. 5000 cal $\mathrm{yr} \mathrm{BP}$, fire frequency decreased between ca. 2300 and $1200 \mathrm{cal} \mathrm{yr} \mathrm{BP,} \mathrm{a} \mathrm{pattern} \mathrm{that} \mathrm{dom-}$ inates at time scales of ca 750-3500 yr and suggests a mechanism in addition to vegetation change. Oxygen isotope records from the region suggest a $2000-y$ r period of moister climatic conditions from 2800-800 cal yr BP (Clegg and $\mathrm{Hu}$, in press) and increased summer moisture may have decreased the probability of ignition and fire spread. Taken together, the fire-frequency variations exhibit (1) prominent changes at multi-millennial time scales, coincident with a large-scale shift in vegetation around 5000 cal yr BP (Fig. 7a-b); and (2) changes at millennial and multi-centennial time scales that are likely a response to changes in fire- 
climate on short time scales (Fig. 7c). In combination with other sites in this region, shorter centennial-scale variability may become apparent as well. Thus, our understanding of a fire regime and its vegetation and climatic controls is tightly linked to the time scale of consideration. Controls at one time scale may not explain patterns at larger time scales, and likewise, patterns over short time scales (even when integrated across space) may not reveal the full suite of mechanisms controlling fire regimes.

\section{THE FIRE REGIME CONCEPT REVISITED}

This examination of fire on different time scales suggests the need to extend traditional time frames for understanding fire regimes. Current definitions that only consider fire activity over decades or centuries are too short to capture the full range of fire variability in many ecosystems. Inferring the fire-regime characteristics on an abbreviated time scale necessarily leads to incomplete or erroneous assumptions about the drivers of fire and the role of fire as an ecosystem process. It also obfuscates the long-term relationships between people and fire in particular ecosystems and the degree to which modern fire regimes are altered from their prehistoric condition. In some regions, fire-history data suggest that fire frequency has been steadily increasing over the past several millennia, whereas in other areas it has been decreasing as a result of long-term climate and vegetation change. Still, other regions show relatively stable fire frequencies over millennia but high stochastic variability at century time scales.

Fire management based on time-since-last-fire statistics overlook long-term patterns that comprise the fire regime. These statistics are at best imprecise and at worst inaccurate. What may be mistaken as a non-stationary response on a short time scales becomes explainable as part of the historic fire-climate or fire-vegetation linkages when viewed on longer time scales. For example, current fire-regime condition classes, which measure the departure of a fire regime from a reference condition, are based on the premise that fire suppression in western U.S. pine forests has moved fire regimes beyond the historical range of variability. Longer tree-ring records and charcoal data in such systems suggest that current fire regimes in some regions are different than $19^{\text {th }}$ century ones, but not beyond the capacity of those forest types (e.g., Sherriff and Veblen 2007; Anderson et al., 2008).

To adequately capture the importance of long-term processes, we conceptualize a "super-fire regime" that describes the characteristic nature of fire within a biome, integrating all possible variations in climate, fuel properties, and human influences (so long as the biome continues to exist). The super-fire regime defines true "historical range of variability" and thus aids in anticipating future variability within a given biome. Most biomes form and persist over centuries to millennia, as a response to long-term climate changes. Definitions of fire regimes that based on too short a time span may misrepresent underlying fire-fuel linkages and create false impressions about current fire hazard. In boreal forests of Alaska, for example, fire statistics vary across a range of temporal scales over the last 5000 years, and the site-specific mean FRIs cover nearly all the variability we see across modern Alaskan boreal forest vegetation. Understanding the role of fire in shaping ecosystem dynamics and resilience requires information on the full temporal expression of fire. The critical time span is determined by the climatic and vegetation conditions that define $t_{\text {stable }}$. In some ecosystems $t_{\text {stable }}$ is reached in decades, whereas in other ecosystems, it may require millennia. Because fire is a process operating on multiple time scales, paleoecological data can help separate the importance of fire-climate and vegetation changes occurring over time scales of centuries to millennia from the importance of fireweather, fuels, and stochasticity on shorter time scales.

Finally, the fire-regime concept should consider the role of people, both in the past and at present. Long time frames help indicate places where recent human activities have severely altered prehistoric fire regimes, as well as where prehistoric people had great impact. Human influence may be highly focused in some ecosystems and broadly felt in others. In "intermediate ecosystems" where neither fuel nor ignitions limit fire occurrence, humans as fire starters, fire suppressors, or fire eliminators can and have had serious consequences and led to irreversible biome transformation. Today, we must consider the role of humans in the fireregime triangle as climate changers, which is an added dimension. A more robust conception of fire regimes that considers temporal and spatial limits of human influences is thus an important step in targeting global fire "hot spots" in the future.

\section{ACKNOWLEDGEMENTS}

This study was supported by grants from the National Science Foundation (ATM-0714061; EAR-0818467; BSC0645821) to CW and a National Park Ecological Research Fellowship to PEH. Virginia Iglesias and two anonymous reviewers provide helpful comments on the manuscript.

\section{REFERENCES}

Agee, JK (1993) Fire Ecology of Pacific Northwest Forests. Washington, DC: Island Press.

Allen, CD (2002) In: Vale, TR (Ed.) Fire, Native Peoples, and the Natural Landscape. Washington, DC: Island Press 143-193.

Anderson, RS, Allen, CD, Toney, JL, Jass, RB \& Bair, AN (2008) Holocene vegetation and fire regimes in subalpine and mixed conifer forests, southern Rocky Mountains, USA. International Journal of Wildland Fire, 17, 96-114.

Anderson, A (2002) Faunal collapse, landscape change and settlement history in remote Remote Oceania. World Archaeology, 33, 375-90.

Archibald, S, Roy, DP, van Wilgen, BW \& Scholes, RJ (2009) What limits fire? An examination of drivers of burnt area in southern Africa. Global Change Biology, 15, 613-30.

Baker, WL (2009) Fire Ecology in Rocky Mountain Landscapes. Washington, DC: Island Press.

Baker, WL (1989a) Landscape ecology and nature reserve design in the Boundary Waters Canoe Area, Minnesota. Ecology, 70, 23-35.

Baker, WL (1989b) Effect of scale and spatial heterogeneity on fire-interval distributions. Canadian Journal of Forest Research, 19, 700-06.

Bartlein, PJ, Hostetler, SW, Shafer, SL, Holman, JO \& Solomon, AM (2008) Temporal and spatial structure in a daily wildfire-start data set from the western United States (1986-1996). International Journal of Wildland Fire 17, 8-17.

Bartlein, PJ, Anderson, KH, Anderson PM, Edwards, ME, Mock CJ, Thompson, RS, Webb, RS, Webb T III \& Whitlock, C (1998) Paleoclimatic simulations for North America over the past 21,000 years: features of the simulated climate and comparisons with 
paleoenvironmental data. Quaternary Science Reviews, 17, 549585.

Beaty, RM \& Taylor, AH (2008) Fire history and the structure and dynamics of a mixed conifer forest landscape in the northern Sierra Nevada, Lake Tahoe Basin, California, USA. Forest Ecology and Management, 255, 707-19.

Bigler, C, Gavin, DG, Gunning, C \& Veblen, TT (2007) Drought induces lagged tree mortality in a subalpine forest in the Rocky Mountains. Oikos, 116, 1983-94.

Bird, BR, Bird, DW, Codding, BF, Parker, CH \& Jones, JH (2008) The "fire stick farming" hypothesis: Australian Aboriginal foraging strategies, biodiversity, and anthropogenic fire mosaics. Proceedings of the National Academy of Sciences, 105, 14796-801.

Black, MP, Mooney, SD \& Haberle, SG (2007) The fire, human and climate nexus in the Sydney Basin, eastern Australia. The Holocene, 17, 469-80.

Bond, WJ, Woodward, FI \& Midgley, GF (2005) The global distribution of ecosystems in a world without fire. New Phytologist, 165, 525-37.

Bowman, DMJS, Balch, JK, Artaxo, P, Bond, WJ, Carlson, JM, Cochrane, MA, D'Antonio, CM, DeFries, RS, Doyle, JC, Harrison, SP, Johnston, FH, Keeley, JE, Krawchuk, MA, Kull, CA, Marston, JB, Moritz, MA, Prentice, IC, Roos, CI, Scott, AC, Swetnam, TW, van der Werf, GR \& Pyne, SJ (2009) Fire in the Earth System. Science, 324, 481-84.

Bradshaw, RHW \& Lindbladh, M (2005) Regional spread and stand-scale establishment of Fagus sylvatica and Picea abies in Scandinavia. Ecology, 86, 1679-86.

Briles, CE, Whitlock, C, Bartlein, PJ \& Higuera, P (2008) Regional and local controls on postglacial vegetation and fire in the Siskiyou Mountains, northern California, USA. Palaeogeography Palaeoclimatology Palaeoecology, 265, 159-69.

Briles, CE (2008) Holocene vegetation and fire history of the floristically diverse Klamath Mountains, northern California, USA. Dissertation. Department of Geography. Eugene, University of Oregon.

Briles, CE, Whitlock, C \& Bartlein, PJ (2005) Postglacial vegetation, fire, and climate history of the Siskiyou Mountains, Oregon, USA. Quaternary Research, 64, 44-56.

Brown, PM (2006) Climate effects on fire regimes and tree recruitment in Black Hills ponderosa pine forests. Ecology, 87, 2500-10.

Brubaker, LB, Higuera, PE, Rupp, TS, Olson, M, Anderson, PM \& Hu, FS (2009) Linking sediment-charcoal records and ecological modeling to understand causes of fire-regime change in boreal forests. Ecology, 90, 1788-801.

Brunelle, A, Whitlock, C, Bartlein, P \& Kipfmueller, K (2005) Holocene fire and vegetation along environmental gradients in the Northern Rocky Mountains. Quaternary Science Reviews, 24, 2281-300.

Burchard, I (1998) Anthropogenic impact on the climate since man began to hunt. Palaeogeography, Palaeoclimatology, Palaeoecology, 139, $1-14$.

Bush, MB \& Silman, MR (2007) Amazonian exploitation revisited: ecological asymmetry and the policy pendulum. Frontiers in Ecology and the Environment, 5, 457-65.

Bush, MB, Silman, MR, de Toledo, MB, Listopad, C, Gosling, WD, Williams, C, de Oliveira, PE \& Krisel, C (2007) Holocene fire and occupation in Amazonia: records from two lake districts. Philosophical Transactions of the Royal Society B-Biological Sciences, 362, 209-18.

Bush, MB, Miller, MC, De Oliveira, PE \& Colinvaux, PA (2000) Two histories of environmental change and human disturbance in eastern lowland Amazonia. The Holocene, 10, 543-53.

Carcaillet, C, Bergman, I, Delorme, S, Hornberg, G \& Zackrisson, O (2007) Long-term fire frequency not linked to prehistoric occupations in northern Swedish boreal forest. Ecology, 88, 465-77.

Carcaillet, C, Almquist, H, Asnong, H, Bradshaw, RHW, Carrion, JS, Gaillard, MJ, Gajewski, K, Haas, JN, Haberle, SG, Hadorn, P, Muller, SD, Richard, PJH, Richoz, I, Rosch, M, Goni, MFS, von Stedingk, H, Stevenson, AC, Talon, B, Tardy, C, Tinner, W, Tryterud, E, Wick, L \& Willis, KJ (2002) Holocene biomass burning and global dynamics of the carbon cycle. Chemosphere, 49, 845-63.

Clark, JS, Grimm, EC, Donovan, JJ, Fritz, SC, Engstrom, DR \& Almendinger, JE (2002) Drought cycles and landscape responses to past aridity on prairies of the northern Great Plains, USA. Ecology, $83,595-601$.
Clark, JS \& Royall, PD (1996) Local and regional sediment charcoal evidence for fire regimes in presettlement northeastern North America. Journal of Ecology, 84, 365-82.

Clark, JS \& Royall, PD (1995) Transformation of a northern hardwood forest by aborginal (Iroquois) fire: evidence from Crawford Lake, Ontario, Canada. The Holocene, 5, 1-9.

Clark, JS (1989) Ecological disturbance as a renewal process: theory and application to fire history. Oikos, 56, 17-30.

Clegg, BC \& Hu, FS (in press) A centennial-scale record of Holocene effective moisture in the southern Brooks Range, Alaska. Quaternary Science Reviews.

Cochrane, MA \& Barber, BP (2009) Climate change, human land use and future fires in the Amazon. Global Change Biology, 15, 601-12.

Cochrane, M (2003) Fire science for rainforests. Science, 421, 913-19.

Cochrane, MA, Alencar, A, Schulze, MD, Souza, CM, Jr., Nepstad, DC, Lefebvre, P \& Davidson, EA (1999) Positive feedbacks in the fire dynamics of closed canopy tropical Forests. Science, 284, 1832-35.

Conedera, M, Tinner, W, Neff, C, Meurer, M, Dickens, AF \& Krebs, P (2009) Reconstructing past fire regimes: methods, applications, and relevance to fire management and conservation. Quaternary Science Reviews, 28, 555-76.

Cook, ER, Woodhouse, CA, Eakin, CM, Meko, DM, Stahle, DW (2004) Long-term aridity changes in the western United States, Science, 306, 1015-18.

Cordeiro, RC, Turcq, B, Suguio, K, da Silva, AO, Sifeddine, A \& VolkmerRibeiro, C (2008) Holocene fires in East Amazonia (Caraja's), new evidences, chronology and relation with paleoclimate. Global and Planetary Change, 61, 49-62.

Dantonio, CM \& Vitousek, PM (1992) Biological invasions by exotic grasses, the grass fire cycle, and global change. Annual Review of Ecology and Systematics, 23, 63-87.

Denevan, WM (2003) The native population of Amazonia in 1492 reconsidered. Revista Indias, 62, 175-88.

Denevan, W (1992) The pristine myth: the landscape of the Americas in 1492. Annals of the Association of American Geographers, 83, 369-85.

Duffy, PA, Walsh, JE, Graham, JM, Mann, DH \& Rupp, TS (2005) Impacts of large-scale atmospheric-ocean variability on Alaskan fire season severity. Ecological Applications, 15, 1317-30.

Ekblom, A (2008) Forest-savanna dynamics in the coastal lowland of southern Mozambique since c. AD 1400. The Holocene, 18, 124757.

Falk, DA, Miller, C, McKenzie, D \& Black, AE (2007) Cross-scale analysis of fire regimes. Ecosystems, 10, 809-23.

Fastie, CL (1995) Causes and ecosystem consequences of multiple pathways of primary succession at Glacier Bay, Alaska. Ecology 76, 1899 916.

Fauria, MM \& Johnson, EA (2008) Climate and wildfires in the North American boreal forest. Philosophical Transactions of the Royal Society B-Biological Sciences, 363, 2317-29.

Ferretti, DF, Miller, JB, White, JWC, Etheridge, DM, Lassey, KR, Lowe, DC, Meure, CMM, Dreier, MF, Trudinger, CM, van Ommen, TD \& Langenfelds, RL (2005) Unexpected changes to the global methane budget over the past 2000 Years. Science, 309, 1714-17.

Finney, MA (1995) The missing tail and other considerations for the use of fire history models. International Journal of Wildland Fire, 5, 197202.

Flannigan, MD, Krawchuck, MA, de Groot, WJ, Wotton, BM \& Gowman, LM (2009) Implications of changing climate for global wildland fire. International Journal of Wildland Fire, 18, 483-507.

Flannigan, MD, Logan, JA, Amiro, BD, Skinner, WR \& Stocks, BJ (2005) Future area burned in Canada. Climatic Change, 72, 1-16.

Gavin, DG, Hallett, DJ, Hu, FS, Lertzman, KP, Prichard, SJ, Brown, KJ, Lynch, JA, Bartlein, P \& Peterson, DL (2007) Forest fire and climate change in western North America: insights from sediment charcoal records. Frontiers in Ecology and the Environment, 5, 499-506.

Gavin, DG, Hu, FS, Lertzman, K \& Corbett, P (2006) Weak climatic control of stand-scale fire history during the late Holocene. Ecology, 87, 1722-32.

Gedalof, Z, Peterson, DL \& Mantua, NJ (2005) Atmospheric, climatic, and ecological controls on extreme wildfire years in the northwestern United States. Ecological Applications, 15, 154-74.

Gillson, L \& Ekblom, A (2009) Untangling anthropogenic and climatic influence on riverine forest in the Kruger National Park, South Africa. Vegetation History and Archaeobotany, 18, 171-85. 
Grissino-Mayer, HD (1999) Modeling fire interval data from the American Southwest with the Weibull distribution. International Journal of Wildland Fire, 9, 37-50.

Guyette, R, Muzika, R \& Dey, D (2002) Dynamics of an anthropogenic fire regime. Ecosystems, 5, 472-86.

Haberle, SG \& David, B (2004) Climates of change: human dimensions of Holocene environmental change in low latitudes of the PEPII transect. Quaternary International, 118-119, 165-79.

Haberle, S, Hope, GS \& van der Kaars, S (2001) Biomass burning in Indonesia and Papua New Guinea: natural and human induced fire events in the fossil record. Palaeogeography, Palaeoclimatology, Palaeoecology, 171, 259-68.

Hamel, J (2001) The Archaeology of Otago, Wellington, New Zealand:, Dept. of Conservation.

Heckenberger, MJ, Christian Russell, J, Toney, JR \& Schmidt, MJ (2007) The legacy of cultural landscapes in the Brazilian Amazon: implications for biodiversity. Philosophical Transactions of the Royal Society B: Biological Sciences, 362, 197-208.

Heinselman, ML (1973) Fire in the virgin forests of the Boundary Waters Canoe Area, Minnesota. Quaternary Research, 3, 329-82.

Heyerdahl, EK, Morgan, P \& Riser, JP (2008) Multi-season climate synchronized historical fires in dry forests (1650-1900), northern Rockies, USA. Ecology, 89, 705-16.

Heyerdahl, EK, Brubaker, LB \& Agee, JK (2001) Spatial controls of historical fire regimes: A multiscale example from the interior west, USA. Ecology, 82, 660-78.

Higuera, PE, Brubaker, LB, Anderson, PM, Hu, FS \& Brown, TA (2009) Vegetation mediated the impacts of postglacial climate change on fire regimes in the south-central Brooks Range, Alaska. Ecological Monographs, 79, 201-19.

Higuera, PE, Brubaker, LB, Anderson, PM, Brown, TA, Kennedy, AT \& $\mathrm{Hu}, \mathrm{FS}$ (2008) Frequent fires in ancient shrub tundra: implications of paleorecords for arctic environmental change. PLoS ONE, 3, e0001744.

Hostetler, SW, Bartlein, PJ, Holman, JO, Solomon, AM \& Shafer, SL (2003) Using a regional climate model to diagnose climatological and meteorological controls of wildfire in the western United States. 5th Symposium on Fire and Forest Meteorology, and 2nd International Wildland Fire Ecology and Fire Management Congress American Meteorological Society. Orlando, FL,1.3, 1-5.

Hu, FS, Brubaker, LB, Gavin, DG, Higuera, PE, Lynch, JA, Rupp, TS \& Tinner, W (2006) How climate and vegetation influence the fire regime of the Alaskan Boreal Biome: the Holocene perspective. Mitigation and Adaptation Strategies for Global Change, 11, 82946.

Huber, UM, Markgraf, V \& Schabitz, F (2004) Geographical and temporal trends in Late Quaternary fire histories of Fuego-Patagonia, South America. Quaternary Science Reviews, 23, 1079-97.

Iniguez, JM, Swetnam, TW \& Yool, SR (2008) Topography affected landscape fire history patterns in southern Arizona, USA. Forest Ecology and Management, 256, 295-303.

Johnson, EA (1992) Fire and vegetation dynamics: studies from the North American boreal forest, Cambridge: Cambridge University Press.

Kasischke, ES, Williams, D \& Barry, D (2002) Analysis of the patterns of large fires in the boreal forest region of Alaska. International Journal of Wildland Fire, 11, 131-44.

Keeley, JE (2004) Native American impact on fire regimes. Fire Management Today, 64, 15-16.

Keeley, JE \& Fotheringham, CJ (2003) In: Veblen, TT, Baker, WL, Montenegro, G \& Swetnam, TW (Eds.) Fire and Climatic Change in Temperate Ecosystems of the Western Americas. New York: Springer 218-262.

Kershaw, AP, Bretherton, SC \& van der Kaars, S (2007) A complete pollen record of the last $230 \mathrm{ka}$ from Lynch's Crater, north-eastem Australia. Palaeogeography Palaeoclimatology Palaeoecology, 251, 23-45.

Kirch, P \& Kahn, J (2007) Advances in Polynesian prehistory: a review and assessment of the past decade (1993-2004). Journal of Archaeological Research, 15, 191-238.

Kirch, PV (1996) Late Holocene human-induced modifications to a central Polynesian island ecosystem. Proceedings of the National Academy of Sciences, 93, 5296-300.

Kitzberger, T, Brown, PM, Heyerdahl, EK, Swetnam, TW \& Veblen, TT (2007) Contingent Pacific-Atlantic Ocean influence on multicentury wildfire synchrony over western North America. Proceedings of the National Academy of Sciences, 104, 543-48.
Kitzberger, T \& Veblen, TT (2003) In: Veblen, TT, Baker, WL, Montenegro, G, \& Swetnam, TW (Eds.) Fire Regimes and Climatic Change in Temperate Ecosystems of the Western Americas. Berlin: Springer-Verlag 290-315.

Krawchuk, MA, Moritz, MA, Parisien, MA, Van Dorn, J \& Hayhoe, K (2009) Global pyrogeography: the current and future distribution of wildfire. PLoS ONE, 4, e5102.

Lawrence, D (2004) Erosion of tree diversity during 200 years of shifting cultivation in Bornean rain forest. Ecological Applications, 14 1855-69.

Lejju, BJ, Taylor, D \& Robertshaw, P (2005) Late-Holocene environmental variability at Munsa archaeological site, Uganda: a multicore, multiproxy approach. The Holocene, 15, 1044-61.

Lertzman, K, Fall, J \& Dorner, B (1998) Three kinds of heterogeneity in fire regimes: At the crossroads of fire history and landscape ecology. Northwest Science 72, 4-23.

Littell, JS, McKenzie, D, Peterson, DL \& Westerling, AL (2009) Climate and wildfire area burned in western U.S. ecoprovinces, 1916-2003. Ecological Applications, 19, 1003-21.

Long, CJ, Whitlock, C, Bartlein, PJ \& Millspaugh, SH (1998) A 9000-year fire history from the Oregon Coast Range, based on a highresolution charcoal study. Canadian Journal of Forest Research 28, 774-87

Lynch, JA, Clark, JS \& Stocks, BJ (2004) Charcoal production, dispersal and deposition from the Fort Providence experimental fire: Interpreting fire regimes from charcoal records in boreal forests. Canadian Journal of Forest Research, 34, 1642-56.

Lynch, JA, Clark, JS, Bigelow, NH, Edwards, ME \& Finney, BP (2003) Geographic and temporal variations in fire history in borea ecosystems of Alaska. Journal of Geophyscial Research, 108, 1-17.

Marlon, JR, Bartlein, PJ, Walsh, MK, Harrison, SP, Brown, KJ, Edwards, ME, Higuera, PE, Power, MJ, Anderson, RS, Briles, C, Brunelle, A, Carcaillet, C, Daniels, M, Hu, FS, Lavoie, M, Long, C, Minckley, T, Richard, PJH, Scott, AC, Shafer, DS, Tinner, W, Umbanhowar, CE \& Whitlock, C (2009) Wildfire responses to abrupt climate change in North America. Proceedings of the National Academy of Sciences of the United States of America, 106, 2519-24.

Marlon, JR, Bartlein, PJ, Carcaillet, C, Gavin, DG, Harrison, SP, Higuera, PE, Joos, F, Power, MJ \& Prentice, IC (2008) Climate and human influences on global biomass burning over the past two millennia. Nature Geoscience, 1, 697-702.

Marlon, J, Bartlein, PJ \& Whitlock, C (2006) Fire-fuel-climate linkages in the northwestern USA during the Holocene. The Holocene, 16, 1059-71.

Mayle, FE, Burbridge, R \& Killeen, TJ (2000) Millennial-scale dynamics of southern Amazonian rain forests. Science, 290, 2291-94.

McGlone, MS \& Wilmshurst, JM (1999) Dating initial Māori environmental impact in New Zealand. Quaternary International, 59, 5-16.

McWethy, DB, Whitlock, C, Wilmshurst, JM, McGlone, MS, \& Li, X (2009) Rapid deforestation of South Island, New Zealand by early Polynesian fires. The Holocene, 19, 883-97.

Meggers, BJ (2003) In: Bradshaw, GA \& Marquet, PA (Eds.) How Landscapes Change. Berlin-Heidelberg: Springer-Verlag 89-110.

Miller, GH, Fogel, ML, Magee, JW, Gagan, MK, Clarke, SJ \& Johnson, BJ (2005) Ecosystem collapse in Pleistocene Australia and a human role in megafaunal extinction. Science, 309, 287-90.

Millspaugh, SH, Whitlock, C \& Bartlein, PJ (2004) In: Wallace, LL (Ed.) After the Fires, The Ecology of Change in Yellowstone National Park. New Haven: Yale University Press 10-28.

Millspaugh, SH, Whitlock, C \& Bartlein, PJ (2000) Variations in fire frequency and climate over the past $17,000 \mathrm{yr}$ in central Yellowstone National Park. Geology, 28, 211-14.

Morgan, P, Hardy, CC, Swetnam, TW, Rollins, MG \& Long, DG (2001) Mapping fire regimes across time and space: Understanding coarse and fine-scale fire patterns. International Journal of Wildland Fire, $10,329-42$.

Moritz, MA, Morais, ME, Summerell, LA, Carlson, JM \& Doyle, J (2005) Wildfires, complexity, and highly optimized tolerance. Proceedings of the National Academy of Sciences, 102, 17912-17.

Nepstad, D, Carvalho, G, Cristina Barros, A, Alencar, A, Paulo Capobianco, J, Bishop, J, Moutinho, P, Lefebvre, P, Lopes Silva, U \& Prins, E (2001) Road paving, fire regime feedbacks, and the future of Amazon forests. Forest Ecology and Management, 154, 395-407.

Nevle, RJ \& Bird, DK (2008) Effects of syn-pandemic fire reduction and reforestation in the tropical Americas on atmospheric $\mathrm{CO}_{2}$ during 
European conquest. Palaeogeography, Palaeoclimatology, Palaeoecology, 264, 25-38.

Niemi, GJ, Devore, P, Detenbeck, N, Taylor, D, Lima, A \& Pastor, J (1990) Overview of case studies on recovery of aquatic system from disturbance. Environmental Management, 14, 571-87.

Ogden, J, Basher, L \& McGlone, M (1998) Fire, forest regeneration and links with early human habitation: evidence from New Zealand: Annals of Botany, 81, 687-96.

Parisien, MA \& Moritz, MA (2009) Environmental controls on the distribution of wildfire at multiple spatial scales. Ecological Monographs, 79, 127-54.

Pierce, JL, Meyer, GA \& Jull, AJT (2004) Fire-induced erosion and millennial scale climate change in northern ponderosa pine forests. Nature, 432, 87-90.

Power, MJ, Marlon, J, Ortiz, N, Bartlein, PJ, Harrison, SP, Mayle, FE, Ballouche, A, Bradshaw, RHW, Carcaillet, C, Cordova, C, Mooney, S, Moreno, PI, Prentice, IC, Thonicke, K, Tinner, W, Whitlock, C, Zhang, Y, Zhao, Y, Ali, AA, Anderson, RS, Beer, R, Behling, H, Briles, C, Brown, KJ, Brunelle, A, Bush, M, Camill, P, Chu, GQ, Clark, J, Colombaroli, D, Connor, S, Daniau, AL, Daniels, M, Dodson, J, Doughty, E, Edwards, ME, Finsinger, W, Foster, D, Frechette, J, Gaillard, MJ, Gavin, DG, Gobet, E, Haberle, S, Hallett, DJ, Higuera, P, Hope, G, Horn, S, Inoue, J, Kaltenrieder, P, Kennedy, L, Kong, ZC, Larsen, C, Long, CJ, Lynch, J, Lynch, EA, McGlone, M, Meeks, S, Mensing, S, Meyer, G, Minckley, T, Mohr, J, Nelson, DM, New, J, Newnham, R, Noti, R, Oswald, W, Pierce, J, Richard, PJH, Rowe, C, Goni, MFS, Shuman, BN, Takahara, H, Toney, J, Turney, C, Urrego-Sanchez, DH, Umbanhowar, C, Vandergoes, M, Vanniere, B, Vescovi, E, Walsh, M, Wang, X, Williams, N, Wilmshurst, J \& Zhang, JH (2008) Changes in fire regimes since the Last Glacial Maximum: an assessment based on a global synthesis and analysis of charcoal data. Climate Dynamics, 30, 887-907.

Pyne, SJ (2001) Fire: A Brief History. Seattle: University of Washington Press.

Pyne, S, Andrews, P \& Laven, R (1996) Introduction to Wildland Fire. New York: Wiley.

Retallack, G (2001) Cenozoic expansion of grasslands and climatic cooling. The Journal of Geology, 109, 407-426.

Romme, WH (1982) Fire and landscape diversity in subalpine forests of Yellowstone-National-Park. Ecological Monographs, 52, 199-221.

Rothermel, RC (1972) A mathematical model for predicting fire spread in wildland fuels. Ogden, UT, Research paper, INT-115. USDA Forest Service, Intermountain Research Station.

Ruddiman, WF (2003) The anthropogenic greenhouse era began thousands of years ago. Climatic Change, 61, 261-93.

Russell, EWB (1983) Indian-set fires in the forests of the northeastern United States. Ecology and Society, 64, 78-88.

Schoennagel, T, Veblen, TT, Kulakowski, D \& Holz, A (2007) Multidecadal climate variability and climate interactions affect subalpine fire occurrence, western Colorado (USA). Ecology, 88, 2891-2902.

Scott, L (2002) Microscopic charcoal in sediments: Quaternary fire history of the grassland and savanna regions in South Africa. Journal of Quaternary Science, 17, 77-86.

Sherriff, RL \& Veblen, TT (2007) A spatially-explicit reconstruction of historical fire occurrence in the ponderosa pine zone of the colorado front range. Ecosystems, 10,311-23.

Skinner, CN, Taylor, AH, \& Agee, JK (2006) In: Sugihara, NS, van Wagtendonk, JW, Fites-Kaufmann, J, Shaffer, K, \& Thode, A (Eds.) Fire in California Ecosystems. Berkeley: University of California Press 170-194.

Skinner, WR, Stocks, BJ, Martell, DL, Bonsal, B \& Shabbar, A (1999) The association between circulation anomalies in the mid-troposphere and area burned by wildland fire in Canada. Theoretical and Applied Climatology, 63, 89-105.

Sprugel, DG (1991) Disturbance, equilibrium, and environmental variability: what is "natural" vegetation in a changing environment? Biological Conservation, 58, 1-18.

Sprugel, DG (1976) Dynamic structure of wave-regenerated Abies balsamea forests in northeastern United-States. Journal of Ecology, 64, 889911.

Ssemmanda, I, Ryves, D, Bennike, 0 \& Appleby, PG (2005) Vegetation history in western Uganda during the last 1200 years: a sedimentbased reconstruction from two crater lakes. The Holocene, 15, 11932.
Storm, L \& Shebitz, D (2006) Evaluating the purpose, extent, and ecological restoration applications of indigenous burning practices in Southwestern Washington. Ecological Restoration, 24, 256-68.

Styger, E, Rakotondramasy, HM, Pfeffer, MJ, Fernandes, ECM \& Bates, DM (2007) Influence of slash-and-burn farming practices on fallow succession and land degradation in the rainforest region of Madagascar. Agriculture, Ecosystems \& Environment, 119, 257-69.

Swetnam, TW \& Betancourt, JL (1998) Mesoscale disturbance and ecological response to decadal climatic variability in the American Southwest. Journal of Climate, 11, 3128-47.

Swetnam, TW (1993) Fire History and Climate-Change in Giant Sequoia Groves. Science, 262, 885-89.

Taylor, AH \& Skinner, CN (2003) Spatial patterns and controls on historical fire regimes and forest structure in the Klamath Mountains. Ecological Applications, 13, 704-19.

Taylor, AH \& Skinner, CN (1998) Fire history and landscape dynamics in a late-successional reserve, Klamath Mountains, California, USA. Forest Ecology and Management, 111, 285-301.

Taylor, D, Robertshaw, P \& Marchant, RA (2000) Environmental change and political-economic upheaval in precolonial western Uganda. The Holocene, 10, 527-36.

Taylor, D, Marchant, R \& Robertshaw, P (1999) Late glacial-Holocene history of lowland rain forest in central Africa: a record from Kabata Swamp, Ndale volcanic field, Uganda. Journal of Ecology, 87, 303-15.

Thompson, JR, Spies, TA \& Ganio, LM (2007) Reburn severity in managed and unmanaged vegetation in a large wildfire. Proceedings of the National Academy of Sciences, 104, 10743-48.

Thonicke, K, Prentice, IC \& Hewitt, C (2005) Modeling glacial-interglacial changes in global fire regimes and trace gas emissions. Global Biogeochemical Cycles, 19, doi:10.1029/2004GB002278.

Tibby, J, Kershaw, A, Builth, H, Philibert, A \& White, C (2006) In: David, B, Barker, B \& McNiven, I (Eds.) The Social Archaeology of Indigenous Societies: Essays on Aboriginal History in Honour of Harry Lourandos. Canberra: Aboriginal Studies Press 254-269.

Tinner, W \& Lotter, AF (2006) Holocene expansions of Fagus silvatica and Abies alba in Central Europe: where are we after eight decades of debate? Quaternary Science Reviews, 25, 526-49.

Trouet, V, Taylor, AH, Carleton, AM \& Skinner, CN (2006) Fire-climate interactions in forests of the American Pacific Coast. Geophysical Research Letters, 33, L18704, doi:10.1029/2006GL027502.

Turner, MG \& Romme, WH (1994) Landscape dynamics in crown fire ecosystems. Landscape Ecology, 9, 59-77.

Turner, MG, O'Neill, RV, Gardner, RH \& Pearson, SM (1993a) Multiscale organization of landscape heterogeneity. Eastside Forest Ecosystem Health Report, Volume II. Ecosystem management: principles and applications. Washington, DC, USDA Forest Service.

Turner, MG, Romme, WH, Gardner, RH \& O'Neill, RV (1993b) A revised concept of landscape equilibrium: Disturbance and stability on scaled landscapes. Landscape Ecology, 8, 213-27.

Turney, CSM \& Hobbs, D (2006) ENSO influence on Holocene aboriginal populations in Queensland, Australia. Journal of Archaeological Science, 33, 1744-48.

Turney, CSM, Kershaw, AP, Moss, P, Bird, MI, Fifield, LK, Cresswell, RG, Santos, GM, Di Tada, ML, Hausladen, PA \& Zhou, Y (2001) Redating the onset of burning at Lynch's Crater (North Queensland): implications for human settlement in Australia. Journal of Quaternary Science, 16, 767-71.

Uhl, C \& Kaufmann, JB (1990) Deforestation, fire susceptibility, and potential tree responses to fire in the eastern Amazon. Ecology, 71, 437-49.

Valsecchi, V, Finsinger, W, Tinner, W \& Ammann, B (2008) Testing the influence of climate, human impact and fire on the Holocene population expansion of Fagus sylvatica in the southern Prealps (Italy). The Holocene, 18, 603-14.

Veblen, TT, Kitzberger, T \& Donnegan, J (2000) Climatic and human influences on fire regimes in ponderosa pine forests in the Colorado Front Range. Ecological Applications, 10, 1178-95.

Walsh, MK, Whitlock, C \& Bartlein, PJ (2008) A 14,300-year-long record of fire-vegetation-climate linkages at Battle Ground Lake, southwestern Washington. Quaternary Research, 70, 251-64.

Weber, MG \& Flannigan, MD (1997) Canadian boreal forest ecosystems structure and function in a changing climate: impact on fire regimes. Environmental Reviews, 5, 145-66. 
Wehrli, M, Tinner, W \& Ammann, B (2007) 16000 years of vegetation and settlement history from Egelsee (Menzingen, central Switzerland). The Holocene, 17, 747-61.

White, PS \& Pickett. STA (1985) In: Pickett, STA \& White, PS (Eds.) The ecology of natural disturbance and patch dynamics, New York: Academic Press 3-13.

Whitlock, C, Marlon, J, Briles, C, Brunelle, A, Long, C, \& Bartlein, PJ (2008) Long-term relations among fire, fuel, and climate in the northwestern US based on lake-sediment studies. International Journal of Wildland Fire, 17, 72-83.

Whitlock, C, Moreno, PI \& Bartlein, PJ (2007) Climatic controls of Holocene fire patterns in southern South America. Quaternary Research, 68, 28-36.
Whitlock, C, Shafer, SH \& Marlon, J (2003) The role of climate and vegetation change in shaping past and future fire regimes in the northwestern U.S., and the implications for ecosystem management. Forest Ecology and Management, 178, 5-21.

Whitlock, C \& Knox, MA (2002) In: Vale, TR (Ed.) Fire, Native Peoples, and the Natural Landscape. Washington, DC: Island Press 195231.

Williams, JW \& Jackson, ST (2007) Novel climates, no-analog plant communities, and ecological surprises: past and future. Frontiers in Ecology and Evolution, 5, 475-82.

Received: September 02, 2009

Revised: November 07, 2009

Accepted: November 09, 2009

(C) Whitlock et al.; Licensee Bentham Open.

This is an open access article licensed under the terms of the Creative Commons Attribution Non-Commercial License (http://creativecommons.org/licenses/by$\mathrm{nc} / 3.0 /$ ), which permits unrestricted, non-commercial use, distribution \& reproduction in any medium, provided the work is properly cited. 